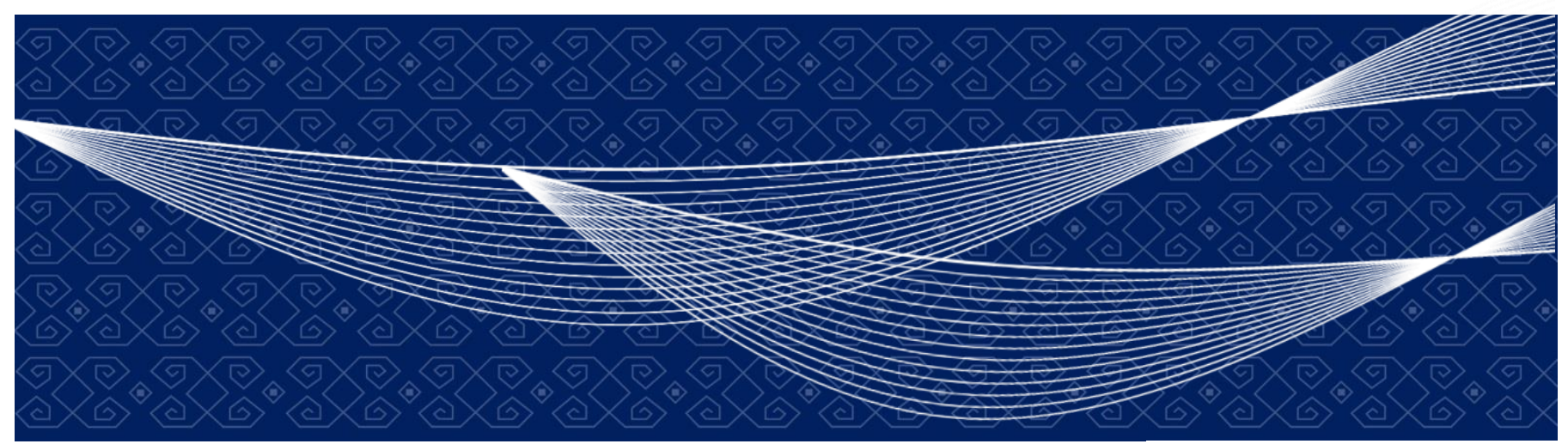

$\mathrm{WP} / 3 / 2020$

WORKING PAPER

SPATIAL WAGE DIFFERENTIALS AND

AGGLOMERATION EXTERNALITIES: EVIDENCE FROM INDONESIAN MICRODATA

Masagus M. Ridhwan

2020

This is a working paper, and hence it represents research in progress. This paper represents the opinions of the authors, and is the product of professional research. It is not meant to represent the position or opinions of the Bank Indonesia. Any errors are the fault of the authors. 


\title{
Spatial Wage Differentials and Agglomeration Externalities: Evidence from Indonesian Microdata
}

\author{
Masagus M. Ridhwan
}

\begin{abstract}
This paper aims to examine sources of labor wage differentials and to investigate human capital externalities across Indonesian districts. Our study attempts to fill the gap in the standard literature, which mainly asserts the key role of labor market characteristics in explaining the disparities. Based on microdata on individual workers from 2006-2015, we found that not only individual (labor) characteristics play a role in explaining the wage variations, but also regional endowments and agglomeration forces. The latter mainly results from spatial proximity of firms to other firms, from labor market pooling, and from knowledge spillovers. In addition, we also found strong evidence of positive human capital externalities, particularly in agglomerated regions. All in all, these findings may suggest the importance of skills and agglomeration for policymakers in boosting local productivity vis-à-vis reducing income/wage inequality.
\end{abstract}

Keyword: Local labor markets; Spatial wage differentials; Panel data analysis JEL Classification: R23; J31; J61

With the usual disclaimer we are grateful to Mr. Solikin M. Juhro and Mr. Reza Anglingkusumo, Daniel Suryadarma, Michiel Gerritse and seminar participants at Bank Indonesia Jakarta (June'2020) for their feedback and comments. The outstanding research assistance of Affandi Ismail is greatly appreciated. Corresponding author: Masagus M. Ridhwan, Bank Indonesia. Email: mha_ridhwan@bi.go.id 


\section{Introduction}

Wage disparity, or income inequality in general, might be one of the world's most contentious topics of debate for economists today. Wage disparities are reflected by individual labor characteristics and regional characteristics that may affect workers' productivity. The problem may not only exist from an international perspective, but also from a regional perspective within a country, particularly developing ones (Ravallion, 2014; van der Hoeven, 2019).

In theoretical terms, analysis of the determining factors of labor wage variation commonly refers to the seminal work of Mincer (1974), who asserted that the wages are mostly attributed to individual worker characteristics, namely individual skills, age, gender, experience, etc. Arrow (1962a) also stated the importance of knowledge or learning in the increase of per capita income. Labor skills allow the increase in efficiency and quality of productive activities that on aggregate accelerate regional economic development. Therefore, labor skills are commonly used as a predictor of labor productivity (see, e.g. Bacolod et al., 2009). This classical view, however, tends to undermine the role of geographical forces, as suggested in economic geography literature that regional wage disparities may also arise due to regional differences in endowment factors, and sorting processes of both individuals and firms with different characteristics lead to agglomeration economies (further details, see, e.g. Krugman, 1991; Combes and Gobillon, 2015).

The premise of agglomeration forces may affect wage and regional productivity refers back to the original work of Marshall (1890), which was then improved by Arrow (1962b) and Romer (1986). The latter theory, simply called as MAR, posits that agglomeration externalities may arise due to: (i) knowledge spillovers between firms; (ii) highly specialized labor forces based on the accumulation of human capital; or (iii) backward and forward linkages associated with large local markets. Glaeser and Mare (2001) pointed out that highly skilled (productive) workers tend to sort to large cities in order to receive higher wages and to develop their skills. In contrast to the MAR theory, Jacobs (1969) argues that the most prominent sources of knowledge spillovers and innovative activity are those resulting from interactions between firms from different industries within a particular region (Beaudry and Schiffauerova, 2009). ${ }^{1}$ Later a pioneering work by Combes et al. (2008) examined the effect of agglomeration externalities on spatial disparities in labor wages across French regions. The disparities could be explained by the following factors: skill composition of the workforce, agglomeration forces (specialization, diversity, competition and density), and non-human endowments such as sea and mountain.

In line with this thinking, our snowballing literature survey also suggests that most of empirical studies have been conducted previously in developed countries, such as in France (Combes et al., 2008); the Netherlands (Groot et al., 2014); the USA (Glaeser and Mare, 2001); the UK (D'Costa and Overman, 2014); and Spain (de la Roca and Puga, 2016). On the other hand, there are only few studies on developing countries, exceptions being on China (Combes et al., 2015), India (Chauvin et al., 2017) and Colombia (Duranton, 2016). Broadly speaking, relevant studies from developing countries remain under-researched (see e.g. Henderson, 2005; Duranton, 2016). For this reason, it would be tempting to contribute to the literature by providing a relevant empirical analysis from a large developing economy, notably Indonesia.

\footnotetext{
${ }^{1}$ In addition, Porter (1990) focuses on the role of competition within local economic or industrial growth (Glaeser et al., 1992). Porter (1990) also states that knowledge spillovers mostly occur in vertically-integrated industries, agreeing with the Marshallian specialization hypothesis (Beaudry and Schiffauerova, 2009).
} 
Next, the main objective of this study is first, to shed light on what factors are able to explain spatial wage differentials across regions in Indonesia, and second, we also aim to examine whether agglomeration may affect human capital externalities. Some of the potential contributions of this paper are as follows. First, in regard to the topic of spatial wage differentials, Indonesia could be an interesting research laboratory for several reasons. As the fourth largest country in terms of population (workforce), Indonesia is also the world's largest archipelagic country; therefore, conducting analysis based on island economies may provide additional insights from the geographical perspective into the domestic labor market. As an archipelago economy, Indonesia is endowed with significant cultural, ethnic, religious and linguistic diversity. ${ }^{2}$ As a relatively more diverse country, Indonesia's wage disparities might be more profound because of the varying characteristics between its regions (see Figure 1).

The second contribution, as aforementioned, is that our analysis is based on a large and unique developing economy, Indonesia. And hence, from an international context, it could be used as a comparative way to examine the differences and similarities of the effects of agglomeration on labor wages between countries, especially between developed and developing countries. In addition, from our survey, we found only few relevant studies of spatial wage differentials in Indonesia, notably Amiti and Cameron (2007) and Kuncoro (2009). ${ }^{3}$ One among other key differences of this study compared to those studies are that first, our empirical analysis focuses on the sources of regional wage differentials, and geographical factors in particular. In doing so, our path of analysis is closely related to those of Combes et al. (2008) and Groot et al. (2014), who underlined the importance of skills composition in the regional labor market, agglomeration forces and local endowments. Another novelty of this study is that we were fortunate to obtain access to a large set of microdata on individual workers across different districts in Indonesia. In this regard, the advantage of using microdata is that they are more explorative and perhaps more robust compared to the aggregate data used in previous studies.

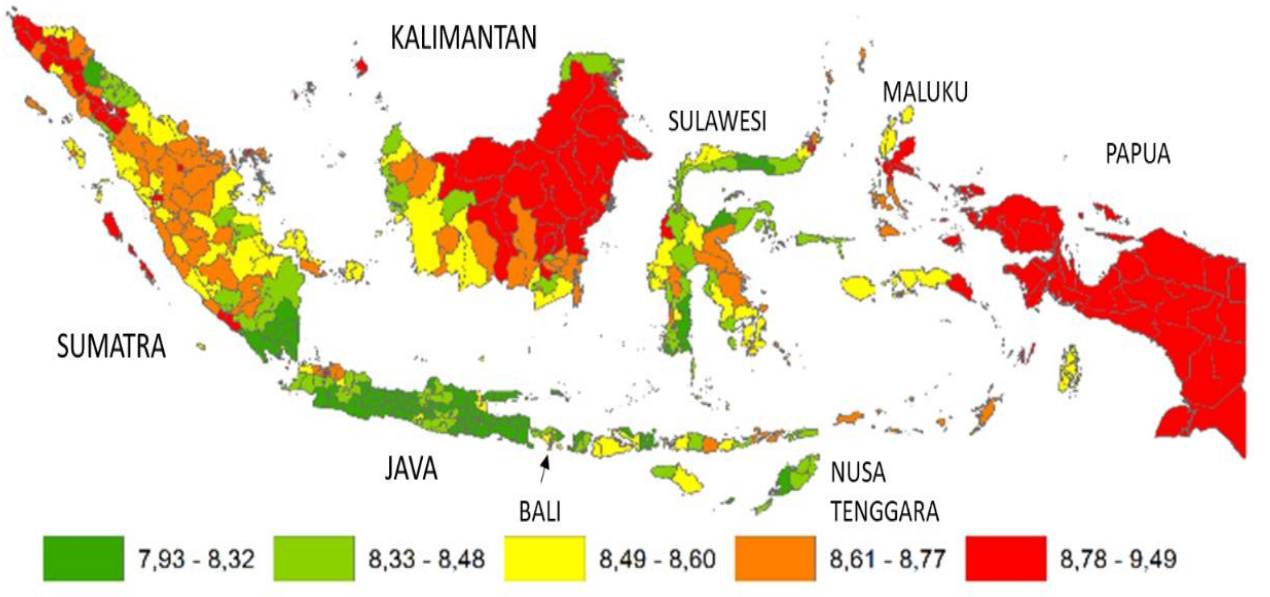

Figure 1 Average Hourly (Log) Real Wage, 2006-2015

\footnotetext{
${ }^{2}$ As an archipelagic country, Indonesia consists of more than 17,000 islands, making it the world's biggest island country, with a land area of around 1.9 million square kilometers. With a population of more than 250 million, it is the fourth most populous country in the world.

3 Based on manufacturing firm-level data from 1996, Amiti and Cameron (2007) estimated the positive agglomeration externalities that arose from demand and cost linkages between firms, leading to wage increases. Based on the same type of data, Kuncoro (2009) examined the determinants of the spatial agglomeration of manufacturing industries on Java island.
} 
This figure illustrates the distribution of the average hourly real wage across Indonesian districts between 2006 and 2015. Overall, cities have higher wages than districts. The dark red colors (Sumatra, Kalimantan and Papua island) appear to dominate in labor markets, but in fact only account for 30 percent of total employment, being mostly in the mining and agricultural sectors. These sectors usually operate across huge areas of land and are capital intensive (e.g. mineral mining and palm oil plantations), with very limited numbers of workers.

Furthermore, we extend the analysis of this study by examining whether skilled workers collocated in urban areas contribute to positive human capital externalities (see, Moretti, 2004a; Rauch, 1993). ${ }^{4}$ The key channels of such externalities may exist through the spillover of ideas among people who interact with each other, and ideas (knowledge) are more likely to spillover from more highly skilled workers than from less-skilled workers, thus resulting in agglomeration forces driving urban productivity as a whole.

In order to achieve the objectives of this study, we first tested the existence of spatial wage differentials across Indonesian districts by following several techniques applied by Combes et al. (2008) and Groot et al. (2014). By utilizing data on individual workers, we first applied the Mincer equation to relate individual wages to worker characteristics and regional dummies. The regional dummy coefficients capture variations in wages that cannot be accounted for by individual characteristics. We then proceeded to the second stage of the wage estimation to identify some of the potentially remaining effects arising from agglomeration externalities. We then also estimated the effect of market access and urban amenities. Finally, we estimated human capital externalities on wages using several estimators and models.

The main findings for the first objective of this study, in particular, are briefly summarized as follows. First, our estimations show positive and significant effects of urban population density on real wages across Indonesian districts. We also found that an increase in specialization (share of local industry) leads to higher productivity. Meanwhile, diversity was found to be negative, and competition positive, with both being significant. Another main finding was that market access has a negative effect on wages, although statistically insignificant. Interestingly, our proxy variable for urban amenities was found to be statistically negative.

Next findings for the second objective, there is compelling evidence that more highly educated (skilled) workforces generate positive human capital externalities. Our study contributes to the literature on labor and regional economics by adding evidence of the existence of spatial wage differentials across regions in Indonesia, which can be attributed to worker characteristics, agglomeration externalities, and human capital externalities. It is also important to note that these differentials are relatively high compared to evidence from developed countries, in particular.

The above findings suggest several policy implications as follows. Firstly, agglomeration economies bring positive externalities to local wages and productivity, and positive human capital externalities may exist due to agglomeration factors. This highlights the importance of skills and agglomeration in increasing productivity. In addition to developing public policies aimed at improving labor productivity, for example through education, training etc., for large developing economies like Indonesia, it is also imperative to enhance connectivity and integration amongst regions, subsequently increasing the mobility of goods, people and ideas. Secondly, while urbanization on Java-Bali has already progressed to the intermediate stage, other regions are still at much earlier stages of urbanization (World Bank, 2018). Therefore, a

\footnotetext{
${ }^{4}$ Duranton (2016) asserted that the notion of human capital externalities means that the availability of more education (or skills) in a city generates social benefits for urban workers, over and beyond the already considerable private benefits of education.
} 
more equal urbanization and human capital development policy are required to ensure that workers across all Indonesian regions enjoy similar benefits from regional skills and agglomeration.

Finally, it is worth noting that while the results of the study appear fairly convincing, some challenges and potential drawbacks may also emerge. Relatively speaking, conducting empirical research based on microdata from developing countries such as Indonesia tends to be more challenging than conducting similar studies in developed countries. For example, the studies conducted in France by Combes et al. (2008) and in the Netherlands by Groot et al. (2014). Typically, our data are unfortunately lacking in the micro details of individual data, as well as in long historical records, given the relatively sheer size in the case of Indonesia, in particular. In terms of methodology, we used multiple approaches, both 2-stage and 1-stage, based on various estimators, and different model specifications were also tested. In addition to the OLS estimator, in order to deal with the potential problem of heteroscedasticity, we also computed a feasible generalized least squares (FGLS) estimator. Moreover, although it is of great interest to deal with endogeneity by employing available instrumental variables (IVs), it was not possible for us to examine lagged density over a long timeframe since the $1800 \mathrm{~s}$, as was conducted in France or the Netherlands, due to a lack of data series. Therefore, Our instruments were only able to refer to the previous fifteen or twenty years of lagged variables. Our data also lack a rich panel of workers to control for unobserved individual characteristics, which may correlate with location choices. For that reason, we share the view of Duranton (2016), who argues that conducting empirical studies on less developed countries requires certain methodological compromises. ${ }^{5}$

This paper is organized as follows, the following section outlines materials and methods used and Section 3 presents the main results and analysis. Finally, section 4 will conclude.

\section{Materials and Methods}

\subsection{Data}

The main data source for the study was the Indonesian National Labor Force Survey (Sakernas), which contains microdata on individual worker characteristics between 2006 and 2015. In Section 4, individual information, including data on wage, education, age, gender, marital status, location, industrial classification, employment status and occupation were required to conduct the Mincerian regression, as they represent the individual characteristics of workers. We included all workers aged 15 and above who were employed and receiving a wage, but excluded those who were self-employed or working without payment. Measures of agglomeration externalities, including specialization, diversity and competition (see Section 3.2), were also constructed using aggregated data from Sakernas. The timeframe of our study is limited to the year 2015 due to the fact that from 2016 onwards Sakernas data are only available at the provincial level, while our study focuses on district-level microdata.

Wages are reported in Sakernas as a monthly wage; we then computed the hourly wage by dividing this using the average working hours per week (hours multiplied by 4, assuming four weeks of work per month). We categorized workers' education levels into those with no schooling, and those whose highest level of education was primary school, junior high school, senior high school, a diploma/polytechnic certificate, or a bachelor-doctoral degree. For industrial classification, we used a 2-digit category based on Indonesia's Standard Industrial Classification (KBLI) from 2005, comprising of 63 industries. We used the number of districts and provinces in 2006 (440 districts and 33 provinces) as the workers' location, meaning that

\footnotetext{
${ }^{5}$ Duranton (2016) examined agglomeration externalities based on Colombian data.
} 
newly formed districts/provinces from 2007-2014 were merged back into their parent region from 2006. ${ }^{6}$ In addition to Sakernas, we also employed the National Socioeconomic Survey (Susenas), to compute the total urban population per region for the whole period of observation. For the total regional population, we used data from the Indonesia Database for Policy and Economic Research (INDO-DAPOER) to construct market access. Further details pertaining to the data used in the study can be found in Appendix 6.

\subsection{Measures of agglomeration externalities}

As predicted by previous theories, agglomeration forces are one of the key factors that may create certain externalities, which result in wage differentials across locations or regions. At this point, we will begin elaborating on how we measured these forces. Agglomeration variables were constructed directly using the microdata to identify employment in each industry and region (see Combes and Gobillon, 2015). First, to capture specialization (MAR externalities), we used the employment share across industries at the district level:

$$
\text { Specialization }_{j, r}=\frac{E_{j, r}}{E_{r}}
$$

where $E_{j, r}$ is the employment for industry- $j$ in region- $r$, and $E_{r}$ is the total employment in region$r$. When industry dummies are included, the log of specialization captures the same effect as a location quotient (Groot et al., 2014). The higher the value of this equation, the higher the share of an industry in the region.

To capture externalities arising from diversity, we then constructed a diversity index as the logarithm of 1 minus the Krugman index (Combes and Gobillon, 2015). The Krugman index is a measure of the distance between the distribution of an industry's share in a certain location and at the global level:

$$
\begin{gathered}
\text { K-index } r \\
=\sum_{j}\left|\frac{E_{j, r}}{E_{r}}-\frac{E_{j}}{E}\right| \\
\text { Diversity }_{r}=\log (1-K \text {-index }
\end{gathered}
$$

where $E_{j}$ is total employment in industry- $j$, and $E$ is total employment in the economy. Diversity is high when regional distribution is identical to global distribution, while an equal share of employment across all industries at the regional level indicates a less diverse environment.

Because of the limitations of the Sakernas data, we were unable to construct regional competition between firms in the same industry. We, therefore, measured competition between industries within the same region. Competition was measured as 1 minus the HirschmanHerfindahl index (HHI) on the distribution of employment across industries in a region:

$$
\text { Competition }_{r}=1-\sum_{j}\left(\frac{E_{j, r}}{E j}\right)^{2}
$$

A high HHI value indicates a lower degree of competition in a region. Since we constructed competition as 1 minus HHI, a high value of competition is associated with fierce competition, while a low value means employment in the region is concentrated in a smaller number of industries. In addition to these externality measurements, we also calculated the urbanization effect of a region based on urban population density at the district level:

\footnotetext{
${ }^{6}$ In the light of the proliferation era, there are 514 districts (kabupaten) and municipalities (kota) registered throughout Indonesia.
} 


$$
\text { Urban Density }_{r}=\frac{\text { Urban Population }_{r}}{\text { Area }_{r}}
$$

The urban population of each region was estimated using Susenas data, with regional areas being obtained from the Ministry of Home Affairs Office (2017) ${ }^{7}$. The urban population is likely to be endogenous to wages. For example, regions experiencing a positive technology shock from a certain stimulus may urbanize faster and attract migrants. To account for endogeneity, we instrumented urban density in 2006-2015 with urban density in 1985 and 1992 (Combes et al., 2008; Graham et al., 2010; Groot et al., 2014). In addition, some alternative instruments were also utilized, including weather conditions (rainfall volumes) and infant mortality rate, which are commonly used to determine institutional development.

Moreover, as asserted by Fujita et al. (1999), regions with better market access, for example, urban areas, can generate higher productivity (higher earnings) because they also tend to benefit from access to large consumer and supplier markets of intermediate inputs (Krugman and Venables, 1995). However, the assumption of labor immobility in this hypothesis may be too tight; in the context of regions within a country, it is possible to allow for some labor mobility. As a consequence, the effects of market access on wages are not necessarily positive or potentially ambiguous (Duranton, 2016). There are several possible effects of better market access, if better market access leads to higher demand for the output of local firms (because buyers can buy at a lower price inclusive of transportation costs) and also to higher productivity (because the firm can purchase intermediate inputs at a lower price), consumers may also pay lower prices for consumption goods. However, better market access may lead to population growth (urbanization), resulting in higher local housing and transportation costs, and consequently lower real wages. ${ }^{8}$ This last effect is also known as the spatial equilibrium hypothesis (Rosen, 1979; Roback, 1982). Market availability in each region was computed by measuring market access for each region as the total population of the other regions divided by their distance:

$$
\text { Market Access }_{r}=\sum_{r^{\prime}} \frac{\text { Population }_{r^{\prime}}}{d_{r, r^{\prime}}}
$$

where Population $r^{\prime}$ signifies the population in other regions, and $d_{r, r}$ 'represents the distance between region- $r$ and region- $r$ '. Therefore, this variable is also useful for representing neighborhood effects (Fafchamps and El Hamine, 2017; Combes et al., 2008).

Furthermore, the spatial equilibrium condition, as mentioned above, may also prevail for local amenities. If a place has attractive amenities (endowment), in the form of both natural features (e.g. climate) and man-made ones (e.g. hospitality services, public facilities, etc.), this results in higher housing costs and lower real wages.

\footnotetext{
7 The urban definition in Susenas is based on a composite scoring system that assesses and scores areas as urban or rural according to four "urban characteristics": population density, proportion of nonagricultural households, presence of certain types of infrastructure (electricity and telephone networks), and the presence of certain urban amenities (schools, hospitals, markets, shops, and recreational facilities, including hotels, cinemas, salons and massage parlors). An area is classified as urban if its score exceeds a set threshold.

${ }^{8}$ Under a simple spatial equilibrium with labor mobility condition: $\left(w_{i}-H_{i}\right) / P_{i}$ is equalized across districts.; (where $H_{i}$ is expenditure on housing and local transportation and $P_{i}$ is the local price index for consumption goods). Therefore, higher or lower wages in big cities which have better market access depending on which effects dominate, and what the main adjustment margin is (for more details, see, Duranton (2016)).
} 


\subsection{Estimation Model and Approach}

In order to explain the spatial wage differentials, we applied a two-stage approach, following Combes et al. (2008) and Groot et al. (2014). In the first step, we began by explaining individual worker characteristics based on the Mincerian approach, which relates wages earned to a series of factors, including individual, industrial and regional characteristics.

$$
\log w_{i, t}=x_{i, t} \varphi+\beta_{r}+\mu_{j}+\delta_{t}+\varepsilon_{i, t}
$$

$x_{i, t}=$ vector of time-varying worker characteristics; $\beta_{r}=$ regional fixed effects;

$\mu_{j}=$ industry fixed effects; $\delta_{t}=$ year fixed effects; and $\varepsilon_{i, t}=$ i.i.d errors assumed across $\mathrm{t}$ and $\mathrm{i}$

$i, j, r$ and $t$ represent the individual, industry/sector, region and year respectively. The Mincer equation estimates wages using workers' individual characteristics (age, education, gender, marital status and occupation), regional characteristics, and industrial characteristics. We used dummy variables for the highest education level achieved by the workers as a proxy for their general skills and knowledge (Groot et al., 2014). We also included age as a proxy for experience, as well as age squared, to account for the non-linear relationship between wages and experience. Occupation dummies may also account for the possibility of a worker not being captured by education or experience. To estimate the regional component of wages, we included dummy variables (440 districts) for the region, and 63 industry fixed effects and year fixed effects.

Next, in order to estimate the effect of agglomeration factors in the second stage of our econometric approach, we re-estimated the fixed effects in equation (6) as a combination of industry, region, and year fixed effects instead of separate dummies as in Groot et al. (2014). We use the combined fixed effect as a dependent variable to be a function of the agglomeration externality measurements, year fixed effects, and industry fixed effects. The combined fixed effects represent spatial residuals, the regional wage after correcting for worker characteristics, and industrial composition.

$$
\beta_{r, j, t}=y_{r, j, t} \gamma+\mu_{j, t}+\delta_{t}+\varepsilon_{i, r, t}
$$

$Y_{r, j, t}=$ vector of geographical variables to capture agglomeration; $\mu=$ industry fixed effects; $\delta=$ year fixed effects

To detect the effects of agglomeration externalities, we implemented a second stage estimation that captured the remaining effects of location-specific characteristics on wages. This two-step approach was used so that we could separate the effect of workers' individual characteristics on wages from the effect of agglomeration. $\beta_{r, j, t}$ represents the spatial residual obtained from the Mincerian regression while $Y_{r, j, t}$ represents the geographical variables that include the externality measurements as previously discussed, namely urban density, specialization, diversity, competition and market access. Equation 7 allowed us to test whether density effects, and MAR, Jacobs and Porter externalities exist in our sample of Indonesian regions.

To further investigate the market access effects on regional productivity differences, we then regressed the logarithm of real wages on a proxy of the explanatory variable (measured as the sum of the population in neighboring districts, adjusted by distance as in Equation 5) and certain control variables. Likewise, we regressed the logarithm of real wages on proxies of amenities and certain related control variables. For human-made amenities, we used number of hotels, restaurants and cafeterias (simply known as horeca) across individual regions as the proxy variable. To capture natural amenities, we employed an absolute value of difference 
between regional temperature and ideal temperature as the proxy variable (Chauvin et al., 2017). Following Combes et al. (2008), we also employed a control variable, area size, to control for the geographical size of a district. To capture specific local developments, we then used the ratio between capital expenditure of the local government and the district population as an additional control variable. The share of highly educated workers was also used to control regional human capital characteristics.

$$
\log w_{i, t}=y_{r, t} \gamma+x_{i, t} \varphi+\mu_{j, t}+\delta_{t}+\partial_{r, t}+\varepsilon_{i, t}
$$

$y_{r, j, t}=$ vector of geographical variables to capture agglomeration; $x_{i, t}=$ vector of individual controls; $\mu_{j, t}=$ industry fixed effects; $\delta_{t}=$ year fixed effects; $\partial_{r, t}=$ regional characteristic controls.

Subsequently, to address the issue of human capital externalities, we examined the existence of knowledge and idea spillover created by human capital, particularly in urbanized regions. Following the method used by Chauvin et al. (2017), we then regressed the logarithm of real wages on area-level education (measured according to the share of workers with upper secondary degrees $)^{9}$, individual education, other demographic variables, and industry, occupation, and year fixed effects, similar to the Mincerian regression in equation (6):

$$
\log w_{i, t}=H C_{r, t} \gamma+x_{i, t} \varphi+\mu_{j, t}+\delta_{t}+\partial_{r, t}+\varepsilon_{i, t}
$$

$H C_{r, t}=$ Area-level education; $x_{i, t}=$ vector of individual controls; $\mu_{j, t}=$ Industry fixed effects; $\delta_{t}$ $=$ Year fixed effects; $\partial_{r, t}=$ Regional characteristic controls

\section{Results and Discussion}

We begin by presenting some stylized facts related to agglomeration externalities based on the measures outlined in Section 3.2. Figure 2 shows the stylized facts with regard to agglomeration measures by district. Urban density is higher on Java Island and in some additional cities outside Java. The distribution of density correlates with the inequality of development across Indonesia, with Java enjoying more urbanization growth, which subsequently attracts more people, thus expanding urban areas on the island.

Specialization, or the share of local industry, tends to be more highly concentrated in regions outside of Java. This phenomenon is mainly caused by the higher land prices in Java, or a specific type of industry that is highly dependent on local-specific factors, for example, resource-based industries. The diversity index is also higher on Java Island, while districts outside Java are relatively more specialized. This fact can be explained by industries that are more willing to establish themselves on Java. Overall, urbanization has resulted in regions being less specialized in certain industries due to an increase in population diversity, the rise of the middle class, and the greater variety of services provided. Urbanized regions can create larger markets and develop knowledge to stimulate diversified economic activities. Nevertheless, this situation appears less likely to occur in industries outside of Java and Bali.

In addition, our competition measure only represents competition between industries within the same region, irrespective of the competition between firms within an industry. As depicted in the lower right panel of Figure 2, competition tends to be higher in Java because

\footnotetext{
${ }^{9}$ While studies in developed countries typically use university degrees to define higher education, we employed upper secondary degrees due to the fact that only around 5-6 percent of the Indonesian working age population have a university degree (Statistics Indonesia, 2015).
} 
the industry group for the Java-Bali districts contains a relatively high number of industries compared to regions outside of Java and Bali.

Regarding wage distribution across economic sectors, mining and quarrying, and social services (including government workers) have the highest wages of all the groups. However, inequality is also highest among the mining and quarrying group, with a Gini Index of 0.47 over the 2006-2015 period (see Appendix 2).
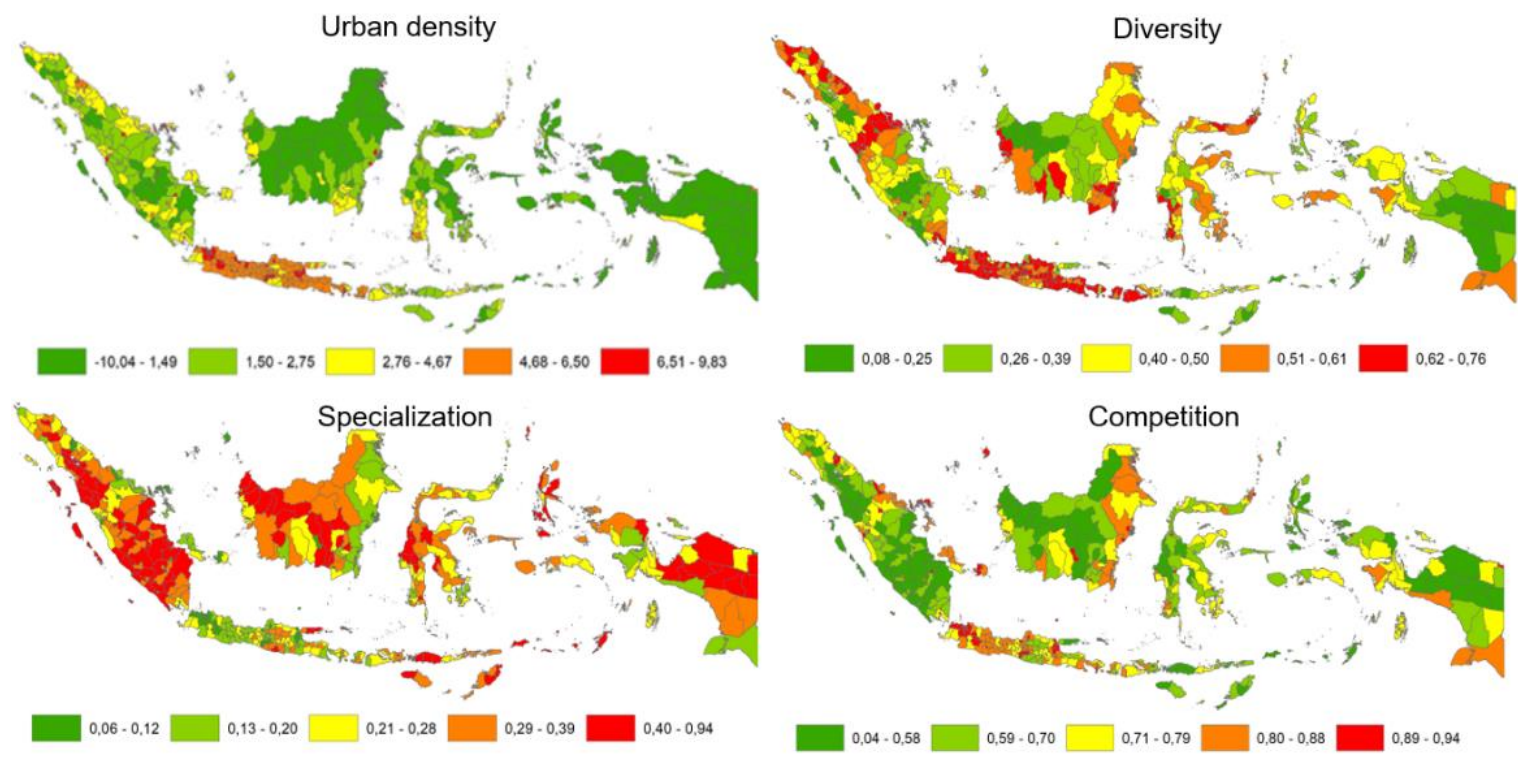

Figure 2: Agglomeration Measures by District, 2006-2015

This figure illustrates the agglomeration characteristics, namely urban density, diversity, specialization, and competition, across districts in Indonesia between 2006 and 2015. Districts in Java and Bali have relatively higher urban density and more diverse industries. Districts outside Java are also more specialized in a few numbers of industry.

By examining new manufacturing firms, it can be observed that Java is still the dominant location preference for industry. For the period of 2005-08, Java was home to 81 percent of medium and large manufacturing firms, producing 75 percent of the total manufacturing output, and hosting 78 percent of the total number of new medium and large manufacturers ${ }^{10}$. In 2011-2015, 82 percent of firms were located in Java and 68 percent of new establishments were also set up on the island (Statistics Indonesia, 2020). The number of both existing and new firms continues to be concentrated in Java, indicating higher agglomeration forces.

Table 1 shows a summary of the descriptive statistics of the data characteristics, which were employed in the two-stage approach of our analysis. Over the period of 2006-2015, there was an increasing pattern of female worker participation and workers with a university degree, especially at the bachelor-doctoral level. Urban density also increased over time, reflecting the progress of urbanization in Indonesia. Meanwhile, the other agglomeration measures (based on Section 3.2) remained relatively stable.

Table 1 Descriptive Statistics

\begin{tabular}{llcc}
\hline & 2006 & 2015 & $2006-2015$ \\
\hline
\end{tabular}

For the $1^{\text {st }}$ stage Mincerian regression

${ }^{10}$ Source: Raharja and Kuncoro (2012) 


\begin{tabular}{lccc}
\hline & 2006 & 2015 & $2006-2015$ \\
Observations & 29,976 & 108,523 & $1,039,096$ \\
Log (Hourly Real Wage) & 8.491 & 8.558 & 8.557 \\
& $(0.777)$ & $(0.948)$ & $(0.885)$ \\
Age & 34.57 & 36.52 & 35.30 \\
Female Workers & $(10.71)$ & $(11.22)$ & $(11.08)$ \\
& 0.329 & 0.352 & 0.340 \\
Married & $(0.470)$ & $(0.478)$ & $(0.474)$ \\
& 0.706 & 0.749 & 0.729 \\
Diploma/Polytechnic & $(0.456)$ & $(0.434)$ & $(0.444)$ \\
& 0.089 & 0.062 & 0.0778 \\
Bachelor-Doctoral & $(0.284)$ & $(0.241)$ & $(0.268)$ \\
& 0.116 & 0.216 & 0.157 \\
& $(0.320)$ & $(0.411)$ & $(0.364)$ \\
\hline
\end{tabular}

For the 2nd Stage (District-Level Variables)

Observations

Log (Urban Density)

$\log$ (Specialization)

$\log$ (Diversity)

Share of Highly Educated Workers

Log (Market Access)

$\log ($ Competition)

$\log ($ Capital/Population)

Absolute Difference from Ideal

Temperature
410

440

3.469

4.298

3.861

(3.645)

(2.624)

$-1.245$

$-1.612$

$-1.480$

(0.639)

(0.616)

(0.639)

$-0.998$

$-0.897$

$-0.935$

(0.735)

(0.516)

(0.574)

0.043

0.086

0.062

(4.574)

(4.323)

(4.059)

7.417

7.440

7.437

(1.621)

(1.653)

(1.646)

$-0.522$

$-0.307$

$-0.374$

(0.540)

(0.289)

(0.386)

12.60

13.71

13.20

(0.994)

(0.930)

(1.076)

13.28

14.09

13.54

(5.189)

(4.610)

(4.983)

1.645

1.939

1.709

(0.728)

(0.573)

(0.643)

This table reports descriptive statistics of the variables used in the regression. The variables are real wage, age, gender dummy, marriage status, and educational attainment dummies for the $1^{\text {st }}$ stage Mincerian regression. For the $2^{\text {nd }}$ Stage, variables used in the regression are urban density, specialization, diversity, share of highly educated workers, market access, competition, ratio of capital expenditures to population, ratio of the number of hotels, restaurants, and cafeterias (horeca) to population, and the absolute difference of the district temperature to the ideal temperature. The statistics reported are mean and standard deviation in 2006, 2015, and average between 2006 and 2015. Standard deviations are shown 
in parentheses. In the $1^{\text {st }}$ stage, we use individual-level observation while in the $2^{\text {nd }}$ stage we use district-level observation.

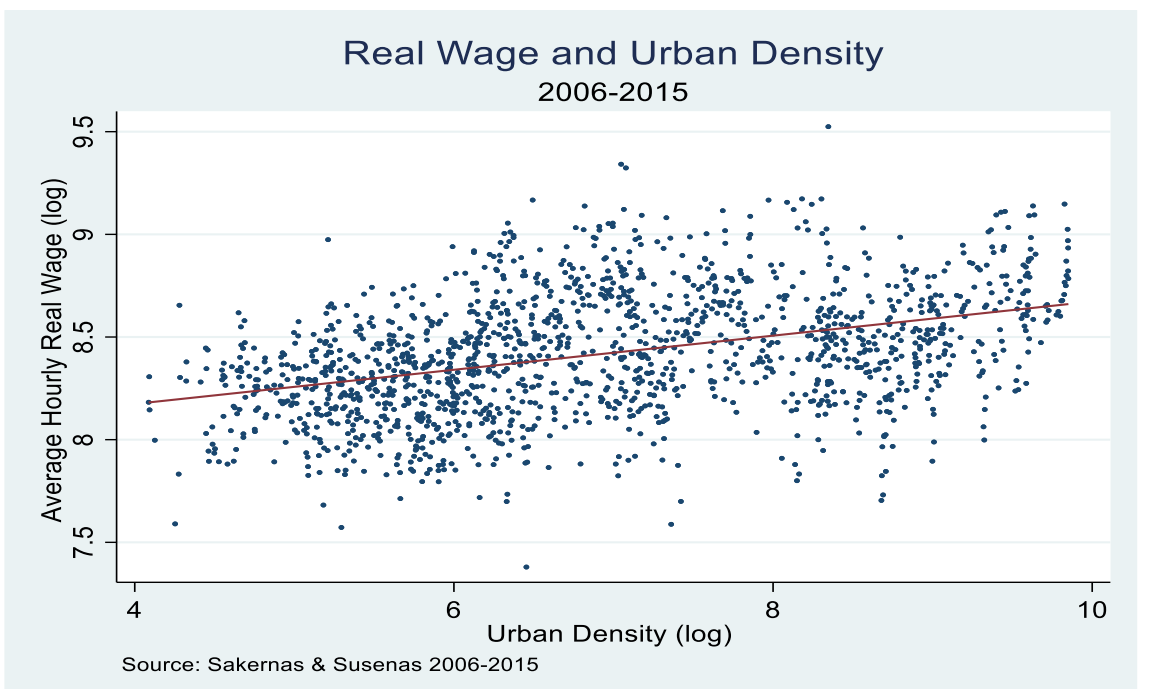

Figure 3 Real wages and urban population density in Indonesian districts, 2006-2015

This figure shows the correlation between real wage and urban density in Indonesian districts between 2006 and 2015. There is a positive correlation between real wage and urban density that confirms our initial hypothesis that more urban areas create higher productivity which is reflected from higher real wage. The coefficient of this correlation is 0.08 and is statistically significant at $1 \%$ level, the R-squared is 0.16 .

Before formally conducting a rigorous empirical test, we began by simply plotting district labor wages and urban population density, and an encouraging sign emerged, with the slope of the regression line being 8 percent and the R-squared 16 percent (Figure 3 ). We then estimated individual wages based on different sets of explanatory variables: regional/location characteristics, individual characteristics, and industry characteristics. A complete computation of the variance analysis can be found in Table 2 and Table 3 below.

Table 2 Explanatory power of individual characteristics and local effects (Equation 6)

\begin{tabular}{lc}
\hline Adj-R $^{2}$ for individual wages in 2006-2015 (log of real wages) as a function of: \\
\hline Regional Effects & 0.08 \\
Individual Characteristics & 0.35 \\
Industry Effects & 0.21 \\
Regional Effects and Individual Characteristics & 0.41 \\
Regional Effects and Industry Effects & 0.27 \\
Individual Characteristics and Regional Effects & 0.38 \\
All Sets & 0.43 \\
\hline Observations & $1,039,096$ \\
\hline
\end{tabular}


Table 3 Variance Analysis

\begin{tabular}{lccc}
\hline \multicolumn{1}{c}{ 2006-2015 } & Mean & St. dev. & $\begin{array}{c}\text { Simple Correlation with } \\
\text { wage }\end{array}$ \\
\hline Log(Hourly Real Wage) & 8.557 & 0.885 & 1 \\
& \multicolumn{2}{c}{ Effect of } \\
Individual Characteristics & 1.337 & 0.567 & $0.56^{\mathrm{a}}$ \\
Age & 0.953 & 0.299 & $0.32^{\mathrm{a}}$ \\
Education & 0.578 & 0.290 & $0.45^{\mathrm{a}}$ \\
Female & -0.056 & 0.078 & $0.10^{\mathrm{a}}$ \\
Marriage & 0.104 & 0.063 & $0.25^{\mathrm{a}}$ \\
Occupation Fixed Effects & -0.241 & 0.168 & $0.42^{\mathrm{a}}$ \\
Industry Fixed Effects & 0.439 & 0.154 & $0.22^{\mathrm{a}}$ \\
De-trended area Fixed & 0.302 & 0.214 & $0.20^{\mathrm{a}}$ \\
Effects & 0.326 & 0.203 & $0.24^{\mathrm{a}}$ \\
Area Fixed Effects & 0.024 & 0.064 & $0.08^{\mathrm{a}}$ \\
Time & $-3.38 \mathrm{E}-11$ & 0.671 & $0.76^{\mathrm{a}}$ \\
Residual & $1,039,096$ & & \\
$\mathrm{~N}$ & & &
\end{tabular}

Notes: Individual characteristics =age+education+female+ marriage+ occupation fixed effects, de-trended area fixed effects=area fixed effects-time; ${ }^{\mathrm{c}} p<0.1,{ }^{\mathrm{b}} p<0.05,{ }^{\mathrm{a}} p<0.01$

The resu The results show that individual characteristics alone explain the majority (35 percent) of the variations in individual wages and that the explanatory power of regional (districts) and industry characteristics explain 27 percent. This early result (variance analysis) confirms that individual labor characteristics play the main role in explaining spatial wage differentials, but that industry and location are also important, coming in second place.

In order to explain the sources of regional wage disparities in Indonesia, as discussed in Section III, we employed a two-stage regression, with the first step (Equation 6) based on the Mincerian approach, followed by an estimation of the log of hourly real wages with several vectors of individual, industrial and regional characteristics. In the second stage (Equation 7), the residual coefficient obtained from the first stage was used as a dependent variable, which was regressed on a vector of geographical variables in order to capture agglomeration effects in districts in Indonesia. As aforementioned, regional labor market composition relates to the characteristics of the individual workers who live and work in the area, whereas regional endowments and agglomeration economies lead to higher productivity for the composition of a given labor market. 
Table 4 Mincerian regression results

\begin{tabular}{|c|c|c|c|c|c|}
\hline Dependent var: & (1) & (2) & (3) & (4) & (5) \\
\hline Log Hourly Wage & 2006 & 2006-2010 & 2011-2015 & 2006-2015 & 2015 \\
\hline \multirow[t]{2}{*}{ Age } & $0.0271^{\mathrm{a}}$ & $0.0284^{\mathrm{a}}$ & $0.0254^{\mathrm{a}}$ & $0.0270^{\mathrm{a}}$ & $0.0216^{\mathrm{a}}$ \\
\hline & $(0.002)$ & $(0.001)$ & $(0.001)$ & $(0.000)$ & $(0.002)$ \\
\hline \multirow[t]{2}{*}{ Age Squared } & $-0.000159^{a}$ & $-0.000152^{\mathrm{a}}$ & $-0.000107^{\mathrm{a}}$ & $-0.000130^{\mathrm{a}}$ & $-0.0000441^{b}$ \\
\hline & $(0.000)$ & $(0.000)$ & $(0.000)$ & $(0.000)$ & $(0.000)$ \\
\hline \multirow[t]{2}{*}{ Female Workers } & $-0.156^{\mathrm{a}}$ & $-0.160^{\mathrm{a}}$ & $-0.168^{\mathrm{a}}$ & $-0.164^{\mathrm{a}}$ & $-0.122^{\mathrm{a}}$ \\
\hline & $(0.008)$ & $(0.002)$ & $(0.002)$ & $(0.002)$ & $(0.005)$ \\
\hline \multirow[t]{2}{*}{ Married } & $0.102^{\mathrm{a}}$ & $0.123^{\mathrm{a}}$ & $0.164^{\mathrm{a}}$ & $0.143^{\mathrm{a}}$ & $0.158^{\mathrm{a}}$ \\
\hline & $(0.010)$ & $(0.003)$ & $(0.003)$ & $(0.002)$ & $(0.007)$ \\
\hline \multicolumn{6}{|l|}{ Education Dummies: } \\
\hline \multirow[t]{2}{*}{ SD/Elementary School } & $0.244^{\mathrm{a}}$ & $0.251^{\mathrm{a}}$ & $0.218^{\mathrm{a}}$ & $0.236^{\mathrm{a}}$ & $0.259^{\mathrm{a}}$ \\
\hline & $(0.034)$ & $(0.009)$ & $(0.011)$ & $(0.007)$ & $(0.027)$ \\
\hline \multirow[t]{2}{*}{ SMP/Junior High School } & $0.410^{\mathrm{a}}$ & $0.419^{\mathrm{a}}$ & $0.405^{\mathrm{a}}$ & $0.414^{\mathrm{a}}$ & $0.459^{\mathrm{a}}$ \\
\hline & $(0.035)$ & $(0.009)$ & $(0.011)$ & $(0.007)$ & $(0.028)$ \\
\hline \multirow{2}{*}{$\begin{array}{l}\text { SMA/Senior } \\
\text { School }\end{array}$} & $0.607^{\mathrm{a}}$ & $0.577^{\mathrm{a}}$ & $0.591^{\mathrm{a}}$ & $0.586^{\mathrm{a}}$ & $0.695^{\mathrm{a}}$ \\
\hline & $(0.035)$ & $(0.009)$ & $(0.011)$ & $(0.007)$ & $(0.028)$ \\
\hline \multirow[t]{2}{*}{ Diploma/Polytechnic } & $0.857^{\mathrm{a}}$ & $0.871^{\mathrm{a}}$ & $0.923^{\mathrm{a}}$ & $0.903^{\mathrm{a}}$ & $1.006^{\mathrm{a}}$ \\
\hline & $(0.037)$ & $(0.010)$ & $(0.012)$ & $(0.008)$ & $(0.030)$ \\
\hline Undergraduate and & $1.010^{\mathrm{a}}$ & $1.048^{\mathrm{a}}$ & $1.153^{\mathrm{a}}$ & $1.094^{\mathrm{a}}$ & $1.265^{\mathrm{a}}$ \\
\hline Postgraduate & $(0.036)$ & $(0.010)$ & $(0.012)$ & $(0.008)$ & $(0.028)$ \\
\hline Region Dummies & Yes & Yes & Yes & Yes & Yes \\
\hline Year Dummies & No & Yes & Yes & Yes & No \\
\hline Industry Dummies & Yes & Yes & Yes & Yes & Yes \\
\hline Occupation Dummies & Yes & Yes & Yes & Yes & Yes \\
\hline Observations & 29,976 & 538,536 & 500,560 & $1,039,096$ & 108,523 \\
\hline Adj. $\mathrm{R}^{2}$ & 0.537 & 0.462 & 0.403 & 0.426 & 0.398 \\
\hline
\end{tabular}

This table reports the $1^{\text {st }}$ stage Mincerian regression based on the following model:

$$
\log w_{i, t}=x_{i, t} \varphi+\beta_{r}+\mu_{j}+\delta_{t}+\varepsilon_{i, t}
$$

Where $\log w_{i, t}$ is the individual $\log$ hourly real wage, $x_{i, t}$ is the vector of time-varying worker characteristics; $\beta_{r}$ is the regional fixed effects $\mu_{j}$ is the industry fixed effects; $\delta_{t}$ is the year fixed effects; and $\varepsilon_{i, t}$ is the i.i.d errors. We use several time periods to check the robustness of the coefficients. Overall, age has the inverted u shape effect to wage and male and married workers have higher wage. Higher education attainment gives higher effect on wage. Robust standard errors in parentheses, ${ }^{\mathrm{c}} p<0.1,{ }^{\mathrm{b}} p<0.05,{ }^{\mathrm{a}} p<0.01$. This table is based on equation (6).

Table 4 shows the estimation results of the Mincerian model for the period of 2006-2015, conducted both in a separate time period and a combined one. The table shows the impact of different worker characteristics on the tendency for their wages to change over time, especially education level and marital status. Education, as a proxy for skills, has positive and significant 
effects on wages, notably university degrees (from tertiary degree/diploma to $\mathrm{Ph} . \mathrm{D}$. level). The elasticity of education with respect to real wages is around 10-12 percent. Previously, Duflo (2001) found the economic returns of education in Indonesia to be around 6.8-10.6 percent. The results from each time period show that all worker characteristics have a significant effect and are consistent in terms of power over the period.

The regional dummies estimated in Table 4 represent the spatial residual, which essentially describes regional wages after correcting for differences in worker heterogeneity and sectoral composition. This residual is presented in Figure 4 and clearly shows there are strong variations in regional wages over the period of 2006-2015. The highest wage premium was paid in the Jakarta area, where a typical worker could expect to earn 47 percent more than the regional average throughout Indonesia. The lowest-paid workers were located in Jember district, at around 85 percent lower than Jakarta (excluding Eastern Indonesia, the least developed region).

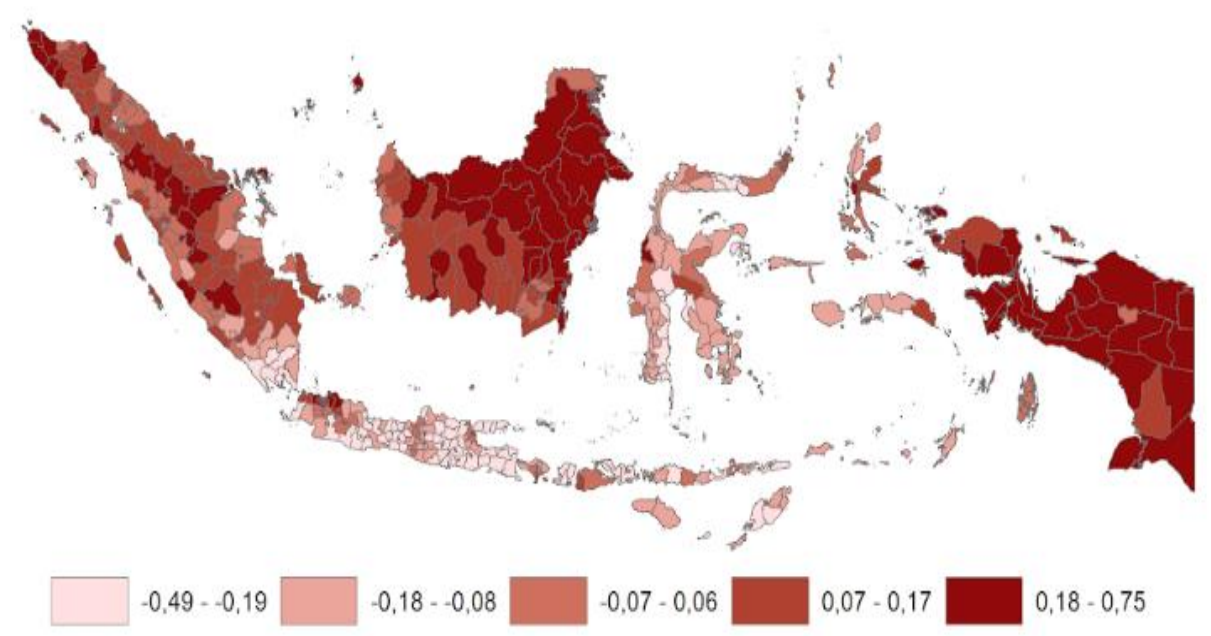

Figure 4: Spatial residual of $(\log )$ real wages

This figure illustrates the distribution of spatial residual of wages in Indonesian districts between 2006 and 2015. The spatial residual is obtained from the Mincerian regression regional dummies estimated in Table 4. There are strong variations in the regional wages even after correcting for individual characteristics and sectoral composition.

In order to discuss the agglomeration externalities in our model, we then proceeded to the second stage of the wage differential analysis by regressing the spatial residual on several vectors of the agglomeration and control variables. By using the spatial residual as a dependent variable, regional wages were isolated from the observed worker characteristics. 
Table 5 Regressions of geographical (agglomeration) variables on spatial residual

\begin{tabular}{|c|c|c|c|c|c|c|}
\hline \multirow{2}{*}{$\begin{array}{l}\text { Dep. Var: } 2^{\text {nd }} \text { stage spatial residual } \\
\text { National }\end{array}$} & \multicolumn{2}{|c|}{ Model 1} & \multicolumn{2}{|c|}{ Model 2} & \multicolumn{2}{|c|}{ Model 3} \\
\hline & OLS & IV & OLS & IV & OLS & IV \\
\hline \multirow[t]{2}{*}{ Log Density } & $0.026^{\mathrm{a}}$ & $0.062^{\mathrm{a}}$ & $0.014^{\mathrm{b}}$ & 0.049 & $0.027^{\mathrm{a}}$ & $0.069^{\mathrm{a}}$ \\
\hline & $(0.005)$ & $(0.017)$ & $(0.005)$ & $(0.035$ & $(0.006)$ & $(0.022)$ \\
\hline \multirow[t]{2}{*}{ Log Specialization } & $0.028^{\mathrm{a}}$ & $0.022^{\mathrm{a}}$ & $0.020^{\mathrm{a}}$ & $0.020^{\mathrm{a}}$ & $0.027^{\mathrm{a}}$ & $0.020^{\mathrm{a}}$ \\
\hline & $(0.004)$ & $(0.004)$ & $(0.003)$ & $(0.003$ & $(0.004)$ & $(0.005)$ \\
\hline \multirow[t]{2}{*}{ Log Diversity } & $-0.093^{\mathrm{a}}$ & $-0.087^{\mathrm{a}}$ & $-0.124^{\mathrm{a}}$ & $-0.101^{\mathrm{a}}$ & $-0.084^{\mathrm{a}}$ & $-0.073^{\mathrm{a}}$ \\
\hline & $(0.016)$ & $(0.015)$ & $(0.016)$ & $(0.028$ & $(0.015)$ & $(0.015)$ \\
\hline \multirow[t]{2}{*}{ Log Area } & $0.063^{\mathrm{a}}$ & $0.109^{\mathrm{a}}$ & $0.065^{\mathrm{a}}$ & $0.100^{\mathrm{a}}$ & $0.061^{\mathrm{a}}$ & $0.110^{\mathrm{a}}$ \\
\hline & $(0.009)$ & $(0.023)$ & $(0.008)$ & $(0.035$ & $(0.008)$ & $(0.027)$ \\
\hline \multirow[t]{2}{*}{ Log Capital/Population } & $0.089^{\mathrm{a}}$ & $0.120^{\mathrm{a}}$ & $0.079^{\mathrm{a}}$ & $0.108^{\mathrm{a}}$ & $0.085^{\mathrm{a}}$ & $0.109^{\mathrm{a}}$ \\
\hline & $(0.008)$ & $(0.017)$ & $(0.008)$ & $(0.032$ & $(0.009)$ & $(0.016)$ \\
\hline \multirow[t]{2}{*}{ Log Competition } & & & $0.205^{\mathrm{a}}$ & 0.085 & & \\
\hline & & & $(0.04)$ & $(0.131)$ & & \\
\hline \multirow[t]{2}{*}{ Log Market Access } & & & & & $-1.086^{\mathrm{b}}$ & $-1.259^{\mathrm{a}}$ \\
\hline & & & & & $(0.546)$ & $(0.489)$ \\
\hline \multirow[t]{2}{*}{ Log Market Access Squared } & & & & & $0.042^{\mathrm{b}}$ & $0.047^{\mathrm{b}}$ \\
\hline & & & & & $(0.021)$ & $(0.019)$ \\
\hline \multirow[t]{2}{*}{ Ratio of Horeca to Population } & & & & & -0.003 & -0.002 \\
\hline & & & & & $(0.002)$ & $(0.002)$ \\
\hline Absolute Difference from Ideal & & & & & $-0.039^{\mathrm{a}}$ & $-0.044^{\mathrm{a}}$ \\
\hline Temperature & & & & & $(0.011)$ & $(0.011)$ \\
\hline Observations & 96,792 & 95,599 & 96,791 & 95,598 & 90,354 & 89,252 \\
\hline Adj. R2 & 0.182 & 0.174 & 0.185 & 0.18 & 0.188 & 0.178 \\
\hline Java-Bali & OLS & IV & OLS & IV & OLS & IV \\
\hline \multirow[t]{2}{*}{ Log Density } & $0.096^{\mathrm{a}}$ & $0.072^{\mathrm{a}}$ & $0.063^{\mathrm{a}}$ & 0.023 & $0.082^{\mathrm{a}}$ & $0.055^{\mathrm{a}}$ \\
\hline & $(0.014)$ & $(0.016)$ & $(0.018)$ & $(0.020)$ & $(0.015)$ & $(0.017)$ \\
\hline \multirow[t]{2}{*}{ Log Specialization } & $0.018^{\mathrm{a}}$ & $0.022^{\mathrm{a}}$ & $0.013^{\mathrm{a}}$ & $0.014^{\mathrm{a}}$ & $0.017^{\mathrm{a}}$ & $0.020^{\mathrm{a}}$ \\
\hline & $(0.005)$ & $(0.005)$ & $(0.004)$ & $(0.004)$ & $(0.005)$ & $(0.005)$ \\
\hline \multirow[t]{2}{*}{ Log Diversity } & $-0.079^{\mathrm{a}}$ & $-0.107^{\mathrm{a}}$ & $-0.108^{\mathrm{a}}$ & $-0.149^{a}$ & $-0.073^{\mathrm{a}}$ & $-0.096^{\mathrm{a}}$ \\
\hline & $(0.025)$ & $(0.028)$ & $(0.025)$ & $(0.027)$ & $(0.023)$ & $(0.025)$ \\
\hline \multirow[t]{2}{*}{ Log Area } & $0.111^{\mathrm{a}}$ & $0.096^{\mathrm{a}}$ & $0.104^{\mathrm{a}}$ & $0.086^{\mathrm{a}}$ & $0.095^{\mathrm{a}}$ & $0.079^{\mathrm{a}}$ \\
\hline & $(0.016)$ & $(0.017)$ & $(0.015)$ & $(0.017)$ & $(0.016)$ & $(0.018)$ \\
\hline \multirow[t]{2}{*}{ Log Capital/Population } & $0.065^{\mathrm{a}}$ & $0.061^{\mathrm{a}}$ & $0.066^{\mathrm{a}}$ & $0.063^{\mathrm{a}}$ & $0.071^{\mathrm{a}}$ & $0.067^{\mathrm{a}}$ \\
\hline & $(0.013)$ & $(0.014)$ & $(0.014)$ & $(0.015)$ & $(0.015)$ & $(0.016)$ \\
\hline \multirow{2}{*}{ Log Competition } & & & $0.387^{\mathrm{a}}$ & $0.586^{\mathrm{a}}$ & & \\
\hline & & & $(0.107)$ & $(0.109)$ & & \\
\hline
\end{tabular}


Log Market Access

Log Market Access Squared

Ratio of Horeca to Population

This table reports the $2^{\text {nd }}$ stage regression based on the following model:

$$
\beta_{r, j, t}=y_{r, j, t} \gamma+\mu_{j, t}+\delta_{t}+\varepsilon_{i, r, t}
$$

Where $\beta_{r, j, t}$ is the spatial residual, $Y_{r, j, t}$ is the vector of geographical variables to capture agglomeration; $\mu$ is the industry fixed effects; and $\delta$ is the year fixed effects. Density and specialization have positive effects on wages while diversity has negative effects. Districts on Java and Bali islands show higher urban density elasticity than the rest of Indonesia. Robust standard errors in parentheses, ${ }^{\mathrm{c}} p<0.1,{ }^{\mathrm{b}} p<0.05,{ }^{\mathrm{a}} p<0.01$. The table is based on equation (7).

Table 5 shows the second stage results using the OLS and IV estimators. IV was specifically used to account for the endogeneity issue. ${ }^{11}$ Model 1, our preferred model, shows that the elasticity of wages with respect to density is around 6 percent nationwide. However, if viewed from the regional perspective, districts on Java and Bali islands show higher elasticity than the rest of Indonesia, at around 9 percent. These results confirm that wages are higher in larger and denser urban areas. As previously mentioned, Java island is known to be the most developed urban area, as well as the most populous location in Indonesia (see Section II).

The coefficient of specialization (MAR externalities) was also found to be positive and significant, at around 2 percent, meaning regions with higher industrial specialization have higher wages. Meanwhile, the impact of diversity (Jacobs externalities) was found to be significantly negative (for further explanation, see the discussion in Table 6). ${ }^{12}$ As previously mentioned, our data only allowed us to use the 2-digit industry group as a basis for competition externalities in line with Porter, with the results being significantly positive for both districts at the national level and Java and Bali.

As highlighted by Groot et al. (2014), aggregate regional data (especially average sectoral composition and worker characteristics) do not sufficiently correct for worker and firm characteristics (Combes et al., 2008; Duranton and Puga, 2004), meaning its estimation results in an upward bias (Melo et al., 2009; Smit, 2010). In this case, we also used individual workers' microdata to estimate agglomeration externalities on regional productivity. Also, as an alternative to the two-stage approach in explaining the determinants of productivity between regions, we employed a single-stage approach. ${ }^{13}$ Instead of first estimating the spatial residual,

\footnotetext{
${ }^{11}$ Note that if using IV results in substantially different results, it is likely that the OLS estimates were biased due to the presence of endogeneity.

${ }^{12}$ Further discussion on the issues of agglomeration externalities can be found in Combes and Gobillon (2015).

13 The estimation method has also been used in recent papers, including Duranton (2016) and Chauvin et al.
} (2017). 
and then using it as a dependent variable in the second stage, this approach directly includes the agglomeration measures and certain regional-level variables (including, area size, ratio between capital expenditure and population, market access, amenities, percentage of highly educated workers, etc.) in a regression of workers' wages on their observable characteristics (see Equation 7).

Table 6 presents the regression results of the single-stage approach. ${ }^{14}$ In Model 1 (our baseline model), the size of density effects is half that of both nationwide and Java-Bali regions compared to the previous 2-stage approach. This may be partially absorbed by the proxy of skills premium (proportion of highly educated workers in urban areas). However, specialization (MAR externalities) is higher (0.025), which means that doubling the share of (2-digit) industries in the local economy may increase regional productivity by, on average, 2.5 percent of the national economy. Again, diversity is found to be statistically negative. As argued by Combes and Gobillon (2015), the estimated effect of diversity to explain productivity is ambiguous and may not be robust; sometimes significantly positive, sometimes significantly negative, and often not significant at all. This may be caused by measurement issues, based on the Herfindahl or Krugman specialization indices (computed based on industry share in the local economy using a relatively aggregate industry classification). It was later argued, for example by Moretti (2004b) in the context of the USA, that it is better to use proximity to estimate spillovers between industries. Furthermore, the share of educated workers is significantly positive, meaning a higher share, by 10 percentage points, of highly educated workers in a region corresponds with an increase in productivity of approximately 7-8 percent. We will examine this human capital issue further in the final section.

In the second model, competition was found to be significant only in the Java-Bali region, and insignificant in the nationwide regression. This finding should be interpreted with caution because we can only measure regional competition between industries within the same region irrespective of competition between firms in the same industry (see section 3.2).

Furthermore, in Model 2, market access was found to be negative, yet statistically insignificant in both the national and Java-Bali models. However, from an economic significance perspective, the negative result may conform with the spatial equilibrium hypothesis, which posits that larger cities have larger populations, and thus higher housing and transportation costs, despite having better market access, in turn, resulting in lower wages. Moreover, the fact that the result for the market access variable becomes positive in squared form may reflect the argument that market access is typically a bell-shaped function of distance to the main population center. Our findings are similar to those of the Colombian study conducted by Duranton (2016), who argues that the negative correlation between market access and urban population can partially be explained by the fact that cities with a higher level of sales than other cities in Colombia tend to be fairly isolated, selling either natural resources or agricultural commodities. This case is quite similar to the context of Indonesia, where natural resource-producing regions are mostly located outside Java and Bali islands and have limited access to external markets.

\footnotetext{
${ }^{14}$ The results of the coefficients from FGLS are relatively similar to the OLS results.
} 
Table 6 Explaining Regional Productivity Differences

\begin{tabular}{|c|c|c|c|c|c|c|c|c|}
\hline \multirow{3}{*}{$\begin{array}{l}\text { Dependent var: } \\
\text { Log hourly real wage }\end{array}$} & \multicolumn{4}{|c|}{ Indonesia } & \multicolumn{4}{|c|}{ Java-Bali } \\
\hline & \multicolumn{2}{|c|}{ Model 1} & \multicolumn{2}{|c|}{ Model 2} & \multicolumn{2}{|c|}{ Model 1} & \multicolumn{2}{|c|}{ Model 2} \\
\hline & OLS & IV & OLS & IV & OLS & IV & OLS & IV \\
\hline \multirow[t]{2}{*}{ Log Density } & $0.029^{\mathrm{a}}$ & $0.036^{\mathrm{a}}$ & $0.017^{\mathrm{c}}$ & 0.037 & $0.057^{\mathrm{a}}$ & $0.043^{\mathrm{a}}$ & 0.005 & 0.024 \\
\hline & $(0.006)$ & $(0.012)$ & $(0.009)$ & $(0.034)$ & $(0.013)$ & $(0.015)$ & $(0.017)$ & $(0.021)$ \\
\hline \multirow[t]{2}{*}{ Log Specialization } & $0.025^{\mathrm{a}}$ & $0.025^{\mathrm{a}}$ & $0.025^{\mathrm{a}}$ & $0.026^{\mathrm{a}}$ & $0.018^{\mathrm{b}}$ & $0.019^{\mathrm{b}}$ & $0.014^{\mathrm{b}}$ & $0.013^{\mathrm{b}}$ \\
\hline & $(0.004)$ & $(0.004)$ & $(0.004)$ & $(0.004)$ & $(0.008)$ & $(0.008)$ & $(0.007)$ & $(0.007)$ \\
\hline \multirow[t]{2}{*}{ Log Diversity } & $-0.051^{\mathrm{a}}$ & $-0.050^{\mathrm{a}}$ & $-0.053^{\mathrm{a}}$ & $-0.043^{\mathrm{b}}$ & $-0.037^{\mathrm{c}}$ & $-0.049^{\mathrm{b}}$ & $-0.058^{\mathrm{a}}$ & $-0.070^{\mathrm{a}}$ \\
\hline & $(0.013)$ & $(0.013)$ & $(0.015)$ & $(0.021)$ & $(0.021)$ & $(0.022)$ & $(0.021)$ & $(0.023)$ \\
\hline \multirow[t]{2}{*}{ Log Area } & $0.092^{\mathrm{a}}$ & $0.100^{\mathrm{a}}$ & $0.083^{\mathrm{a}}$ & $0.098^{\mathrm{a}}$ & $0.116^{\mathrm{a}}$ & $0.112^{\mathrm{a}}$ & $0.080^{\mathrm{a}}$ & $0.074^{\mathrm{a}}$ \\
\hline & $(0.009)$ & $(0.014)$ & $(0.009)$ & $(0.026)$ & $(0.013)$ & $(0.014)$ & $(0.014)$ & $(0.015)$ \\
\hline \multirow{2}{*}{$\begin{array}{l}\text { Share of highly } \\
\text { educated workers }\end{array}$} & $0.759^{\mathrm{a}}$ & $0.729^{\mathrm{a}}$ & $0.784^{\mathrm{a}}$ & $0.711^{\mathrm{a}}$ & $0.707^{\mathrm{a}}$ & $0.778^{\mathrm{a}}$ & $0.753^{\mathrm{a}}$ & $0.817^{\mathrm{a}}$ \\
\hline & $(0.078)$ & $(0.090)$ & $(0.089)$ & $(0.146)$ & $(0.127)$ & $(0.132)$ & $(0.128)$ & $(0.138)$ \\
\hline \multirow[t]{2}{*}{ Log Capital/Population } & $0.074^{\mathrm{a}}$ & $0.078^{\mathrm{a}}$ & $0.075^{\mathrm{a}}$ & $0.083^{\mathrm{a}}$ & $0.060^{\mathrm{a}}$ & $0.059^{\mathrm{a}}$ & $0.059^{\mathrm{a}}$ & $0.057^{\mathrm{a}}$ \\
\hline & $(0.008)$ & $(0.011)$ & $(0.008)$ & $(0.016)$ & $(0.012)$ & $(0.012)$ & $(0.013)$ & $(0.014)$ \\
\hline \multirow[t]{2}{*}{ Log Competition } & & & 0.035 & -0.017 & & & $0.393^{\mathrm{a}}$ & $0.466^{\mathrm{a}}$ \\
\hline & & & $(0.039)$ & $(0.097)$ & & & $(0.094)$ & $(0.100)$ \\
\hline \multirow[t]{2}{*}{ Log Market Access } & & & -0.128 & -0.201 & & & -0.503 & -0.363 \\
\hline & & & $(0.363)$ & $(0.371)$ & & & $(2.011)$ & $(2.059)$ \\
\hline Log Market Access & & & 0.006 & 0.008 & & & 0.021 & 0.016 \\
\hline Squared & & & $(0.014)$ & $(0.014)$ & & & $(0.073)$ & $(0.075)$ \\
\hline Ratio of Horeca to & & & $-0.004^{b}$ & -0.003 & & & $-0.008^{\mathrm{a}}$ & $-0.008^{\mathrm{a}}$ \\
\hline Population & & & $(0.002)$ & $(0.002)$ & & & $(0.003)$ & $(0.003)$ \\
\hline Absolute Difference & & & $-0.032^{\mathrm{a}}$ & $-0.035^{\mathrm{a}}$ & & & -0.020 & -0.016 \\
\hline from Ideal Temp. & & & $(0.010)$ & $(0.011)$ & & & $(0.016)$ & $(0.016)$ \\
\hline Education Controls & Yes & Yes & Yes & Yes & Yes & Yes & Yes & Yes \\
\hline Demographic Controls & Yes & Yes & Yes & Yes & Yes & Yes & Yes & Yes \\
\hline Occupation Controls & Yes & Yes & Yes & Yes & Yes & Yes & Yes & Yes \\
\hline Industry Controls & Yes & Yes & Yes & Yes & Yes & Yes & Yes & Yes \\
\hline Observations & 926,272 & 916,518 & 921,185 & 911,431 & 363,474 & 363,474 & 363,474 & 363,474 \\
\hline Adj. R2 & 0.396 & 0.395 & 0.397 & 0.397 & 0.447 & 0.447 & 0.450 & 0.450 \\
\hline
\end{tabular}

This table reports the single-stage approach regression based on the following model:

$$
\log w_{i, t}=y_{r, t} \gamma+x_{i, t} \varphi+\mu_{j, t}+\delta_{t}+\partial_{r, t}+\varepsilon_{i, t}
$$

Where $\log w_{i, t}$ is the individual $\log$ hourly real wage, $y_{r, j, t}$ is the vector of geographical variables to capture agglomeration; $x_{i, t}$ is the vector of individual controls; $\mu_{j, t}$ is the industry fixed effects; $\delta_{t}$ is the year fixed effects; and $\partial_{r, t}$ is the regional characteristic controls. The overall signs and significance are similar to Table 5. Meanwhile, the size of density effects is half that of both nationwide and Java-Bali regions compared to the previous 2-stage approach. Robust Standard errors in parentheses; ${ }^{\mathrm{c}} p<0.1,{ }^{\mathrm{b}} p<0.05,{ }^{\mathrm{a}} p<0.01$, this table is based on equation (8). 
In addition, we found horeca (hotel-restaurant-café), as a proxy for human-made amenities, to be significantly negative, despite the size effects being small. ${ }^{15}$ This finding however tends to be in line with the spatial equilibrium prediction that if a region has better amenities (and higher housing costs), then real wages will be lower. However, in the case of Indonesia as an archipelagic country, meaning it is geographically separated, it is also possible for a location to enjoy high wages, but lack amenities, especially outside the Java-Bali area (particularly remote regions). Therefore, real wages may be higher due to barriers to mobility. Interestingly, Bryan and Morten (2019) found that migration costs in Indonesia correlate with distance and that the elasticity of cost to distance is 15 percent, compared to only 2 percent in the U.S.

For a proxy variable for natural amenities, we followed Chauvin et al. (2017) with regard to deviations from the ideal temperature (natural amenities), as measured by the absolute value of the difference between average temperature and the thermal comfort standard. ${ }^{16}$ An interesting finding shown in Model 2 is that the estimated coefficients of ideal temperature (natural amenities) were found to be significantly negative, especially for the Indonesia-wide group, implying that a higher deviation from ideal temperature results in lower real wages. ${ }^{17}$ Although this finding contradicts what Chauvin et al. (2017) found in the U.S., their findings for Brazil are very similar to ours. They later argued that, in Brazil, real wages are higher in more temperate areas, or in other words, nominal wages are much lower in the hottest regions.

The results of the estimation in Table 6 then allowed us to compare wage differences between agglomerated and non-agglomerated districts (see Table 7 below); specifically, we are interested in comparing the size of expected wage differentials with actual wages. ${ }^{18}$ The columns on the right-hand side of Table 7 show the contribution of each component to the expected wage differential. It was calculated that, on average, real wages are 22.53 percent higher in agglomerated districts than in peripheral ones. In line with the estimation results, the right-hand side of the column also supports the major contributions of notable variables, including education, density and diversity, affecting wage differences between districts.

\footnotetext{
${ }^{15}$ During the estimation process, we attempted using several different proxies for the amenities variable, including number of supermarkets, infrastructure (asphalt roads), ruggedness, soil type, and topography; However, here we present only the statistically significant results.

${ }^{16}$ The comfort temperature is set at $25.5^{\circ} \mathrm{C}$ (Indonesian National Standardization / SNI 6390:2011 Building Air Conditioning System Energy Conservation, Badan Standardisasi Nasional (BSN), Indonesia, 2011).

${ }^{17}$ Nevertheless, some cities, such as Batam City in Riau Island, had an average absolute difference of $1.2{ }^{\circ} \mathrm{C}$ in 2006-2015 $\left(0.5^{\circ} \mathrm{C}\right.$ lower than the average absolute difference $)$, and with 21 percent higher wages than the average. In addition, the results shown in Table 10 indicate that on average a $1{ }^{\circ} \mathrm{C}$ deviation from the ideal temperature corresponds with a wage decrease of around 5 to 7 percent. Chauvin et al. (2017) found that a $1^{\circ} \mathrm{C}$ difference from ideal temperature was associated with 4.5 percent decrease in real wages in their Brazil sample.

18 Following Groot et al. (2014), the expected log wage differentials were calculated by multiplying the coefficients that were estimated for municipalities (using the IV estimations) by the average of the independent variables within each agglomeration (in deviation from their non-urbanized counterparts). The definition of agglomeration districts is based on the 2015-2019 RPJMN (Bappenas, 2015).
} 


\section{B BANK INDONESIA}

Table 7: Wage Differences between Agglomerated vs Non-Agglomerated Municipalities

\begin{tabular}{|c|c|c|c|c|c|c|c|c|c|c|c|c|c|}
\hline District/City & $\begin{array}{c}\text { Expected } \\
\text { Wage }\end{array}$ & $\begin{array}{c}\text { Actual } \\
\text { Wage }\end{array}$ & Education & $\begin{array}{c}\text { Urban } \\
\text { Density }\end{array}$ & Diversity & Specialization & Area & Market Access & Capital & Competition & Horeca & Temperature & Industry \\
\hline Bekasi City & 37.59 & 56.72 & 21.61 & 16.26 & 3.91 & -0.91 & -19.32 & 0.90 & -3.17 & -0.12 & 2.37 & -0.90 & 0.06 \\
\hline South Jakarta & 51.17 & 51.26 & 22.82 & 17.24 & 4.59 & 0.12 & -23.20 & 0.98 & 21.65 & -0.10 & 2.15 & -3.65 & -0.09 \\
\hline East Jakarta & 51.61 & 46.61 & 19.95 & 17.08 & 4.62 & -0.70 & -20.28 & 0.98 & 19.60 & -0.11 & 0.61 & -3.69 & -0.01 \\
\hline Central Jakarta & 43.47 & 43.34 & 19.51 & 18.09 & 5.95 & -0.01 & -34.19 & 1.05 & 29.38 & -0.10 & 0.72 & -3.64 & -0.08 \\
\hline North Jakarta & 37.53 & 38.32 & 16.02 & 16.14 & 3.82 & -0.42 & -22.82 & 0.91 & 23.99 & -0.10 & 0.11 & -3.68 & -0.02 \\
\hline West Jakarta & 32.31 & 35.80 & 14.76 & 17.96 & 6.51 & -0.31 & -24.09 & 0.92 & 20.75 & -0.10 & 2.69 & -3.67 & -0.07 \\
\hline Kab Bekasi & 19.98 & 35.76 & 3.05 & 8.99 & 1.73 & -1.19 & -1.16 & 0.72 & -1.50 & -0.12 & 1.54 & -0.88 & 0.16 \\
\hline Karo & 16.21 & 35.41 & 6.25 & -5.45 & 1.63 & -1.39 & 4.47 & -0.35 & 1.67 & 0.31 & -0.26 & -0.62 & -0.04 \\
\hline Depok & 19.29 & 34.12 & 16.14 & 15.22 & 4.51 & -0.51 & -19.64 & 0.89 & -3.82 & -0.11 & 2.69 & -0.93 & -0.04 \\
\hline Denpasar & 13.84 & 31.35 & 20.71 & 13.60 & 6.10 & 0.37 & -24.23 & -0.03 & -5.27 & -0.10 & -0.71 & 0.97 & -0.07 \\
\hline Tangerang City & 15.80 & 28.15 & 15.48 & 16.28 & 4.77 & -0.81 & -22.32 & 0.89 & -2.59 & -0.12 & 1.50 & 1.18 & 0.03 \\
\hline Badung & 16.77 & 27.62 & 12.96 & 6.59 & 0.61 & 0.22 & -12.11 & 0.04 & 8.06 & -0.09 & -3.48 & 0.93 & -0.06 \\
\hline Kab Tangerang & 22.47 & 26.54 & 8.86 & 11.12 & 2.09 & -1.06 & -1.72 & 0.67 & 0.21 & -0.12 & 1.68 & 1.18 & 0.05 \\
\hline Medan & 17.25 & 22.84 & 18.34 & 14.79 & 3.34 & -0.36 & -16.78 & -0.22 & -2.52 & -0.09 & 2.64 & -0.67 & -0.06 \\
\hline Cimahi & 0.80 & 20.71 & 13.89 & 17.17 & 4.10 & 0.18 & -36.27 & 0.76 & -3.45 & -0.10 & 1.49 & -0.92 & -0.01 \\
\hline Sidoarjo & 15.47 & 20.01 & 11.96 & 10.64 & 1.55 & -0.87 & -7.87 & 0.41 & -4.34 & -0.12 & 0.23 & -2.67 & 0.06 \\
\hline Makassar & 22.47 & 16.87 & 19.04 & 14.01 & 5.55 & 0.37 & -19.69 & -0.36 & -4.53 & -0.09 & 1.46 & 1.15 & -0.04 \\
\hline Gresik & 3.93 & 15.64 & 6.99 & 4.60 & 0.04 & -1.06 & -1.44 & 0.27 & -6.43 & -0.11 & -0.50 & -2.76 & 0.06 \\
\hline Bandung City & 9.15 & 14.09 & 15.28 & 17.08 & 4.60 & -0.23 & -21.45 & 0.66 & -3.06 & -0.10 & 0.28 & -0.98 & -0.05 \\
\hline Tabanan & -4.01 & 11.18 & 3.30 & -0.53 & -1.97 & -0.63 & -3.09 & -0.01 & -4.79 & -0.01 & -2.11 & 1.07 & -0.02 \\
\hline Bogor City & 5.24 & 7.60 & 10.69 & 14.96 & 3.66 & -0.16 & -24.99 & 1.03 & -3.20 & -0.10 & 2.05 & -0.93 & -0.05 \\
\hline Surabaya & 10.17 & 7.54 & 14.35 & 14.66 & 4.62 & -0.50 & -13.93 & 0.35 & -1.07 & -0.09 & 1.32 & -2.79 & -0.05 \\
\hline Semarang & 11.11 & 5.51 & 13.99 & 12.20 & 2.89 & -0.50 & -13.27 & 0.42 & -3.01 & -0.11 & 0.99 & -2.17 & -0.04 \\
\hline Deli Serdang & 0.67 & 4.94 & 5.88 & 4.74 & -0.78 & 0.05 & 5.01 & -0.18 & -6.47 & -0.08 & 1.93 & -0.59 & 0.01 \\
\hline Salatiga & -5.49 & 4.29 & 12.45 & 10.94 & 2.01 & -0.09 & -32.40 & 0.56 & 4.65 & -0.10 & -1.69 & -2.15 & -0.05 \\
\hline Mojokerto & -11.10 & 2.31 & 10.89 & 14.34 & 4.04 & -0.27 & -45.13 & 0.50 & 7.24 & -0.09 & -6.11 & -2.82 & 0.04 \\
\hline Maros & 5.54 & 1.21 & 2.58 & -4.71 & -2.20 & -0.37 & 1.69 & -0.30 & 3.99 & -0.03 & -1.08 & 1.07 & 0.01 \\
\hline Kab Bogor & -6.83 & 0.57 & -4.89 & 7.77 & -0.08 & -1.00 & 6.95 & 0.73 & -5.63 & -0.10 & 0.90 & -0.88 & 0.02 \\
\hline Demak & -18.51 & -0.73 & -2.91 & 3.35 & -2.46 & -1.88 & -4.30 & 0.41 & -3.13 & -0.05 & 1.15 & -2.20 & -0.01 \\
\hline Binjai & -10.46 & -0.97 & 9.72 & 12.12 & 2.50 & 0.20 & -32.08 & -0.12 & 2.58 & -0.09 & 1.43 & -0.41 & -0.04 \\
\hline Kab Semarang & -22.93 & -5.50 & -1.91 & 3.03 & -1.97 & -0.67 & -3.75 & 0.49 & -5.07 & -0.06 & 0.42 & -2.47 & 0.01 \\
\hline Gowa & -1.93 & -5.91 & -0.66 & -1.79 & -2.05 & -0.12 & 3.23 & -0.32 & 0.09 & 0.00 & -0.05 & 1.06 & -0.01 \\
\hline Gianyar & -4.46 & -6.45 & 7.71 & 6.11 & 0.12 & 0.19 & -13.43 & -0.01 & -0.67 & -0.08 & -1.60 & 0.98 & -0.05 \\
\hline
\end{tabular}




\section{(B) BANK INDONESIA}

\begin{tabular}{|c|c|c|c|c|c|c|c|c|c|c|c|c|c|}
\hline Grobogan & -21.98 & -6.70 & -8.49 & -2.03 & -1.35 & -1.51 & 3.92 & 0.41 & -7.25 & 0.08 & 0.34 & -2.10 & -0.06 \\
\hline Takalar & -12.35 & -9.72 & -1.35 & -2.82 & -1.83 & 0.34 & -9.03 & -0.31 & 2.50 & -0.05 & 0.07 & 1.06 & 0.00 \\
\hline Mojokerto & -17.30 & -9.89 & -1.10 & 5.28 & -1.34 & -1.13 & -6.61 & 0.43 & -4.47 & -0.09 & -2.04 & -2.81 & 0.05 \\
\hline Kab Bandung & -9.09 & -10.23 & -3.82 & 7.13 & -0.64 & 0.18 & 8.23 & 0.54 & -9.53 & -0.09 & 0.50 & -0.91 & 0.00 \\
\hline Lamongan & -12.06 & -13.59 & -3.55 & -1.08 & -1.97 & -1.31 & 2.67 & 0.34 & -4.39 & 0.03 & -0.55 & -2.80 & -0.06 \\
\hline Kendal & -31.15 & -16.57 & -6.74 & 3.00 & -2.69 & -1.04 & -2.09 & 0.43 & -5.72 & -0.02 & 0.13 & -2.11 & -0.01 \\
\hline Bangkalan & -20.52 & -17.05 & -10.67 & 0.81 & -0.48 & -1.78 & -3.21 & 0.27 & -2.85 & 0.14 & 1.94 & -2.78 & -0.06 \\
\hline Cianjur & -20.11 & -27.24 & -10.29 & 0.07 & -2.32 & -0.42 & 10.50 & 0.47 & -7.61 & 0.01 & 0.31 & -0.89 & -0.01 \\
\hline
\end{tabular}




\section{BANK INDONESIA}

In the last part of our analysis, we will examine whether human capital externalities occurred in our Indonesian data. As explained in the previous section, human capital externalities are a type of positive agglomeration force, which has significant positive effects on underlying productivity in urban areas. Not only do these externalities have a direct effect on labor skills and productivity, but also have influence through the effects of indirect spillover between workers as they learn from each other through, for instance, observation or copycat behavior.

Table 8: Human Capital Externality Regressions, OLS

\begin{tabular}{lcc|cc}
\hline \multirow{2}{*}{$\begin{array}{c}\text { Dependent var. } \\
\text { Log hourly real wage }\end{array}$} & \multicolumn{2}{c|}{ Indonesia } & \multicolumn{2}{c}{ Java-Bali } \\
\cline { 2 - 5 } & Model 1 & Model 2 & Model 1 & Model 2 \\
\hline Share of Highly Educated Workers & $1.538^{\mathrm{a}}$ & $1.908^{\mathrm{a}}$ & $2.269^{\mathrm{a}}$ & $1.432^{\mathrm{a}}$ \\
& $(0.234)$ & $(0.225)$ & $(0.372)$ & $(0.375)$ \\
Log Density & & $0.044^{\mathrm{a}}$ & & $0.088^{\mathrm{a}}$ \\
& & $(0.006)$ & & $(0.013)$ \\
Log Area & & $0.091^{\mathrm{a}}$ & & $0.110^{\mathrm{a}}$ \\
& & $(0.009)$ & & $(0.013)$ \\
Log Capital/Population & & $0.096^{\mathrm{a}}$ & & $0.065^{\mathrm{a}}$ \\
& & $(0.007)$ & & $(0.012)$ \\
Education Controls & Yes & Yes & Yes & Yes \\
Demographic Controls & Yes & Yes & Yes & Yes \\
Occupation Controls & Yes & Yes & Yes & Yes \\
Industry Controls & Yes & Yes & Yes & Yes \\
\hline Observations & $1,039,096$ & 928,921 & 402,743 & 363,759 \\
Adj. R2 & 0.382 & 0.391 & 0.439 & 0.445 \\
\hline
\end{tabular}

This table reports the human capital externalities regression based on the following model:

$$
\log w_{i, t}=H C_{r, t} \gamma^{+} x_{i, t} \varphi+\mu_{j, t}+\delta_{t}+\partial_{r, t}+\varepsilon_{i, t}
$$

Where $\log w_{i, t}$ is the individual log hourly real wage, $H C_{r, t} Y$ is the human capital variable; $x_{i, t}$ is the vector of individual controls; $\mu_{j, t}$ is the industry fixed effects; $\delta_{t}$ is the year fixed effects; and $\partial_{r, t}$ is the regional characteristic controls. We find evidence of positive human capital externalities on wages, increasing the share of highly educated workers by 10 percentage points (Model 1) increased productivity by around 15 percent in the nationwide sample and around 20 percent in Java-Bali island sample. Robust standard errors in parentheses; ${ }^{\mathrm{c}} p<0.1,{ }^{\mathrm{b}} p<0.05,{ }^{\mathrm{a}} p<0.01$. The table is based on equation (9).

We then regressed individual wages on the proportion of highly educated (skilled) workers as our proxy for human capital, together with certain observable worker characteristics, as in the Mincerian regressions, with some geographical and economic variables also included as a control. As shown in Table 8, increasing the share of highly educated workers by 10 percentage points (Model 1) increased productivity by around 15 percent in the nationwide sample and around 20 percent in Java-Bali island sample. Interestingly, by introducing density (Model 2), the skill 


\section{BANK INDONESIA}

premium variable in particular increased by 22 percent nationwide. ${ }^{19}$ Accordingly, it may be argued that having more skilled workers in more urbanized regions tends to result in higher productivity. This finding conforms with Bacolod et al. (2009), who argue that the increase in productivity associated with agglomeration, as measured by the urban wage premium, is higher for workers with higher education (as a proxy for skills). ${ }^{20}$

Our estimated human capital spillover coefficients range from 1.5-2.2 percent for Indonesia, which is somewhat comparable to Chauvin et al. (2017), who found coefficients ranging from 3.04.7 percent for Brazil; 5.2- 7.2 percent for China; and 1.9-3.2 percent for India. The smaller effects for Indonesia compared to these countries is understandable, as only 16 percent of young adults in Indonesia had attained tertiary education in 2017, a lower rate than the G20 average of 38 percent. $^{21}$

Finally, we were tempted to further explore the effects of individual education attainment (dummy of education level) and external human capital (share of highly educated workers). We interacted the individual education dummies with the share of highly educated workers in the region. This approach enabled us to further examine whether there are differences in gains from human capital externalities between workers with different levels of education. Table 9 presents the results of the human capital externality regressions with the addition of the interaction between share of highly educated workers in the region and worker's individual education attainment. Workers with undergraduate to postgraduate degrees tended to gain more from the human capital externalities, with the results showing that a 10 percentage points increase for highly educated workers increases their productivity by 21.84 percent, while for workers with senior high school or lower education productivity only increases by 14.73 percent (Model 1). Similar to the results in Table 9, the human capital spillover premium for workers with undergraduate to postgraduate degrees is also higher in Java and Bali than nationwide.

Table 9: Human Capital Externality Interaction Regressions, OLS

\begin{tabular}{lcc|cc}
\hline \multirow{2}{*}{$\begin{array}{c}\text { Dependent var. } \\
\text { Log hourly real wage }\end{array}$} & \multicolumn{2}{c|}{ Indonesia } & \multicolumn{2}{c}{ Java-Bali } \\
\cline { 2 - 5 } & Model 1 & Model 2 & Model 1 & Model 2 \\
\hline Share of Highly Educated Workers & $1.473^{\mathrm{a}}$ & $1.844^{\mathrm{a}}$ & $1.979^{\mathrm{a}}$ & $1.262^{\mathrm{b}}$ \\
& $(0.376)$ & $(0.373)$ & $(0.373)$ & $(0.523)$ \\
SD/Elementary School & $0.282^{\mathrm{a}}$ & $0.297^{\mathrm{a}}$ & $0.249^{\mathrm{a}}$ & $0.250^{\mathrm{a}}$ \\
& $(0.023)$ & $(0.023)$ & $(0.029)$ & $(0.037)$ \\
SMP/Junior High School & $0.472^{\mathrm{a}}$ & $0.492^{\mathrm{a}}$ & $0.468^{\mathrm{a}}$ & $0.473^{\mathrm{a}}$ \\
& $(0.027)$ & $(0.026)$ & $(0.032)$ & $(0.039)$ \\
SMA/Senior High School & $0.621^{\mathrm{a}}$ & $0.623^{\mathrm{a}}$ & $0.640^{\mathrm{a}}$ & $0.643^{\mathrm{a}}$ \\
& $(0.030)$ & $(0.028)$ & $(0.037)$ & $(0.042)$ \\
Diploma/Polytechnic & $0.960^{\mathrm{a}}$ & $0.955^{\mathrm{a}}$ & $0.994^{\mathrm{a}}$ & $0.997^{\mathrm{a}}$
\end{tabular}

${ }^{19}$ The human capital coefficients in the Java-Bali region, however, tended to decline when we also controlled for urban density, which may be a result of the islands being over-populated (congestion externalities).

${ }^{20} \mathrm{We}$ also tested for complementarity between urban density and human capital by examining the interaction between these two variables. While the interaction term is statistically significant, the share of highly educated workers' coefficient become insignificant. This finding makes the evidence for this complementarity in Indonesia somewhat ambiguous. The results of this regression are available upon request. Duranton (2016) also found no evidence of complementarity between cities and skills in Colombia.

${ }^{21}$ Brazil, China and India are also G20 member countries (see: https://www.oecd.org/education/education-at-aglance/EAG2019_CN_IDN.pdf ) 


\begin{tabular}{lcc|cc} 
& $(0.030)$ & $(0.029)$ & $(0.039)$ & $(0.042)$ \\
Undergraduate and & $1.058^{\mathrm{a}}$ & $1.073^{\mathrm{a}}$ & $1.184^{\mathrm{a}}$ & $1.179^{\mathrm{a}}$ \\
Postgraduate & $(0.032)$ & $(0.031)$ & $(0.045)$ & $(0.048)$ \\
& & & & \\
Share of Highly Educated Workers & & & & \\
SD/Elementary School & -0.417 & $-0.535^{\mathrm{b}}$ & -0.233 & -0.418 \\
& $(0.292)$ & $(0.271)$ & $(0.326)$ & $(0.365)$ \\
SMP/Junior High School & -0.321 & -0.436 & -0.066 & -0.222 \\
& $(0.342)$ & $(0.313)$ & $(0.369)$ & $(0.406)$ \\
SMA/Senior High School & 0.139 & 0.165 & 0.391 & 0.258 \\
& $(0.367)$ & $(0.331)$ & $(0.416)$ & $(0.437)$ \\
Diploma/Polytechnic & -0.149 & -0.011 & 0.416 & 0.267 \\
& $(0.385)$ & $(0.347)$ & $(0.445)$ & $(0.429)$ \\
Undergraduate and & $0.711^{\mathrm{c}}$ & $0.736^{\mathrm{b}}$ & $0.989^{\mathrm{b}}$ & $0.890^{\mathrm{c}}$ \\
Postgraduate & $(0.393)$ & $(0.362)$ & $(0.478)$ & $(0.490)$ \\
Log Density & & $0.044^{\mathrm{a}}$ & & $0.088^{\mathrm{a}}$ \\
& & $(0.006)$ & & $(0.013)$ \\
Log Area & & $0.090^{\mathrm{a}}$ & & $0.110^{\mathrm{a}}$ \\
& & $(0.009)$ & & $(0.013)$ \\
Log Capital/Population & & $0.097^{\mathrm{a}}$ & & $0.065^{\mathrm{a}}$ \\
& & $(0.007)$ & & $(0.012)$ \\
Demographic Controls & Yes & Yes & Yes & Yes \\
Occupation Controls & Yes & Yes & Yes & Yes \\
Industry Controls & Yes & Yes & Yes & Yes \\
\hline Observations & $1,039,096$ & 928,921 & 402,743 & 363,759 \\
Adj. R2 & 0.382 & 0.391 & 0.440 & 0.445 \\
\hline Tis & & &
\end{tabular}

This table reports the human capital externalities regression based on the following model:

$$
\log w_{i, t}=H C_{r, t} \gamma+x_{i, t} \varphi+\mu_{j, t}+\delta_{t}+\partial_{r, t}+\varepsilon_{i, t}
$$

Where $\log w_{i, t}$ is the individual $\log$ hourly real wage, $H C_{r, t} \gamma$ is the human capital variable; $x_{i, t}$ is the vector of individual controls; $\mu_{j, t}$ is the industry fixed effects; $\delta_{t}$ is the year fixed effects; and $\partial_{r, t}$ is the regional characteristic controls. We find that human capital externalities are especially higher for university graduates, 10 percentage points increase for highly educated workers increases their productivity by 21.84 percent, while for workers with senior high school or lower education productivity only increases by 14.73 percent (Model 1). Robust standard errors in parentheses; ${ }^{\mathrm{c}} p<$ $0.1,{ }^{\mathrm{b}} p<0.05,{ }^{\mathrm{a}} p<0.01$. The table is based on equation (9).

\section{Conclusion}

Our analysis was based on individual worker survey data from 440 districts in Indonesia between 2006-2015. We found that strong and persistent wage differentials in the country are mainly explained by individual characteristics, followed by industry and geographical factors. In terms of agglomeration, we found that the elasticity of wages with respect to urban density is approximately 6 percent nationwide and approximately 9 percent for the Java-Bali region. These findings are relatively comparable to previous studies in other developing countries, including China, India and Colombia (Combes et al., 2015; Chauvin et al., 2017; Duranton, 2016). However, 


\section{BANK INDONESIA}

they reveal greater effects compared to developed countries, including the Netherlands and France (Groot et al., 2014; Combes et al., 2008). ${ }^{22}$

Another substantial finding from this study is the significant positive effect of specialization (MAR externalities); doubling the share of the 2-digit industry results in an increase in productivity of around 2-2.8 percent. We also found a negative sign for diversity (Jacob externalities) and a positive sign for competition (Porter externalities). Based on a spatial equilibrium framework with labor mobility, we also found negative effects of market access and amenities on wages. Finally, we found compelling evidence for the occurrence of human capital externalities in Indonesia, with the coefficients ranging from 1.5 to 2.2 percent. Workers with university degrees receive higher human capital externalities.

The above results are very relevant and should be considered by policymakers in formulating public policies regarding issues around the labor market and urbanization, in particular. The strong relationship between urban density and labor wages in Indonesia, compared to those documented in developed countries, suggests the importance of urbanization in driving labor productivity. As for human capital externalities, in addition to increasing their own productivity, workers with high educational attainment also bring positive externalities to other workers in their regions. With the importance of agglomeration factors and human capital in affecting productivity, targeted policies that aim to ensure equal development of urban areas and human capital throughout the nation are certainly required to reduce high wage differentials in Indonesia.

Overall, our findings reveal many important issues in the field of urban economics, especially in the context of developing countries, in particular Indonesia. Despite some challenges in the details of our microdata and measurements, this study is robust with regard to a number of econometric concerns. Urbanization in developing countries around the world is increasing rapidly, yet its effects are much less analyzed compared to the documented evidence in developed countries. As a future scope, a robust research agenda on agglomeration effects in developing countries is much needed to provide policymakers with rich knowledge and insights in order to formulate relevant and evidence-based public policies.

${ }^{22}$ See Combes and Gobillon (2015) for a more comprehensive survey of this issue. 


\section{REFERENCES}

Amiti, M., and Cameron, L. (2007). Economic Geography and Wages. Review of Economics and Statistics, 89(1), 15-29.

Arrow, K. (1962a). The Economic Implications of Learning by Doing. The Review of Economic Studies, 29(3), 155-173

Arrow, K. (1962b). Economic welfare and the allocation of resources for invention, in R. Nelson (ed.). The Rate and Direction of Inventive Activity, Princeton NJ: Princeton University Press.

Bacolod, M, Blum, B. S., and Strange, W. C. (2009). Skills in The City. Journal of Urban Economics, 65, 136-153.

Badan Pusat Statistik, (2015). Keadaan Angkatan Kerja di Indonesia Agustus 2015 (Indonesia Labor Situation August 2015). Jakarta: BPS.

Badan Pusat Statistik, (2020). Jumlah Industri Pengolahan Besar dan Sedang, Jawa dan Luar Jawa (Number of Large and Medium Manufacturing Industries, Java and Outside Java), 20012017. https://www.bps.go.id/statictable/2010/01/18/1053/jumlah-industri- pengo lahanbesar-dan-sedang-jawa-dan-luar-jawa-2001-2017. html

Beaudry, C., and Schiffauerova, A. (2009). Who's right, Marshall or Jacobs? The localization versus urbanization debate. Research Policy, 38(2), 318-337.

Bryan, G., and Morten, M. (2019). The Aggregate Productivity Effects of Internal Migration: Evidence from Indonesia. Journal of Political Economy, 127(5), 2229-2268.

Chauvin, J. P., et. al. (2017). What is Different About Urbanization in Rich and Poor Countries? Cities in Brazil, China, India and United States. Journal of Urban Economics, 98, 17-49.

Combes, P., Duranton, G., and Gobillon, L. (2008). Spatial Wage Disparties: Sorting Matters!. Journal of Urban Economics, 63, 723-742.

Combes, P., and Gobillon, L. (2015). The Empirics of Agglomeration Economies. Handbook of Regional and Urban Economics, 5, 247-348.

Combes, P., Demurger, S., and Li, S. (2015). Migration Externalities in Chinese Cities. Journal of Urban Economics, 76, 152-167.

D'Costa, S., and Overman, H. G. (2014). The urban wage growth premium: sorting or learning?. LSE Research Online Documents on Economics 59074, London School of Economics and Political Science, LSE Library.

De La Roca, J. and Puga, D. (2016). Learning by Working in Big Cities. The Review of Economic Studies, 84(1), 106-142.

Duflo, E. (2001). Schooling and Labor Market Consequences of School Construction in Indonesia: Evidence from an Unusual Policy Experiment. American Economic Review, 91(4), 795813. 


\section{BANK INDONESIA}

Duranton, G., and Puga, D. (2004). Micro-foundations of Urban Agglomeration Economies. Handbook of Regional and Urban Economics, 4, 2064-2117.

Duranton, G. (2016). Agglomeration Effects in Colombia. Journal of Regional Science, 56, 210238.

Fafchamps, M., and Hamine, S.E. (2017). Firm productivity, wages, and agglomeration externalities. Research in Economics, 71(2), 291-305.

Fujita, M., Krugman, P.R., and Venables, A.J. (1999). The Spatial Economy: Cities, Regions, and International Trade. Cambridge, MA: MIT Press.

Glaeser, E., et. al. (1992). Growth in Cities. Journal of Political Economy, 100(6), 1127-1151.

Glaeser, E., and Maré, D. (2001). Cities and Skills. Journal of Labor Economics, 19(2), 316-342.

Graham, D.J., et. al. (2010). Testing for Bi-Directional Causality between Productivity and Agglomeration Economies. Journal of Regional Science, 50(5), 935-951.

Groot, S.P.T., de Groot, H.L.F., and Smit, M.J. (2014). Regional Wage Differences in The Netherlands: Micro Evidence on Agglomeration Externalities. Journal of Regional Science, 54, 503-523.

Henderson, J. V. (2005). Urbanization and Growth. Chapter 24 in Handbook of Economic Growth, 1, Part B, 1543-1591, Elsevier.

Jacobs, J. (1969). The Economy of Cities. New York: Random House.

Krugman, P.R. (1991). Increasing Returns and Economic Geography. Journal of Political Economy, 99(3).

Krugman, P.R., and Venables, A.J. (1995). Globalization and the Inequality of Nations. Quarterly Journal of Economics, 110(4), 857-880.

Kuncoro, A. (2009). Spatial Agglomeration, Firm Productivity, and Government Policies in Indonesia: Concentration and Deconcentration in The Manufacturing Sector. The World Bank: Reshaping Economic Geography in East Asia, 156-168. Policy Note 6: Agglomeration and Manufacturing Activities in Indonesia, World Bank, 2012.

Marshall, A. (1890). Principles of Economics. London: Macmillan.

Melo, P., Graham, D., and Noland, R. (2009), A meta-analysis of estimates of urban agglomeration economies. Regional Science and Urban Economics, 39(3), 332-342.

Mincer, J. (1974). Schooling, Experience and Earnings. National Bureau of Economic Research, New York.

Moretti, E. (2004a). Estimating the Social Return to Higher Education: Evidence from Longitudinal and Repeated Cross-sectional Data. Journal of Econometrics, 121(1), 175212.

Moretti, E. (2004b). Workers' Education, Spillovers, and Productivity: Evidence from Plant-Level Production Functions. American Economic Review, 94(3), 656-690. 


\section{BANK INDONESIA}

Porter, M. (1990). The Competitive Advantage of Nations. London: Macmillan.

Raharja, S., and Kuncoro, A. (2012). Agglomeration and Manufacturing Activities in Indonesia. World Bank Policy Note 6. Jakarta: World Bank Office Jakarta.

Rauch, J.E. (1993). Productivity Gains from Geographic Concentration of Human Capital: Evidence from the Cities. Journal of Urban Economics, 34(3), 380-400.

Ravallion, M. (2014). Income inequality in the developing world. Science, 344, 851-855.

Roback, J. (1982). Wages, Rents, and the Quality of Life. Journal of Political Economy, 90(6), $1257-1278$.

Romer, P. M. (1986). Increasing returns and long-run growth. Journal of Political Economy, 94(5), 1002-37.

Rosen, S. (1979). Wage-based indexes of urban quality of life. In: P. Mieszkowski, and M. Straszheim (Eds.). Current Issues in Urban Economics. 391-429.

Smit, M.J. (2010). Agglomeration and Innovation: Evidence from Dutch Microdata, Ph.D. Dissertation. Department of Spatial Economics, VU University, Amsterdam.

Van der Hoeven, R. (2019). Income Inequality in Developing Countries, Past and Present. In: Nissanke M., Ocampo J. (eds) The Palgrave Handbook of Development Economics. Palgrave Macmillan, Cham.

World Bank (2018). Indonesia Economic quarterly: Urbanization for all. Jakarta: World Bank. 


\section{Appendices}

\section{Proportion of Urban Population and Proportion of Workers in Industry and Services}

Figure 5.1 Proportion of Urban Population

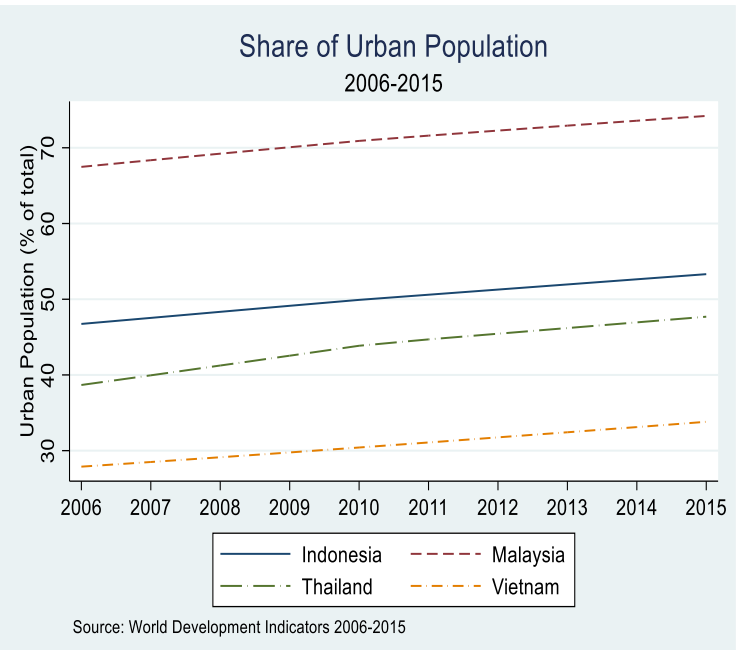

Figure 5.2 Proportion of Workers in Industry and Services

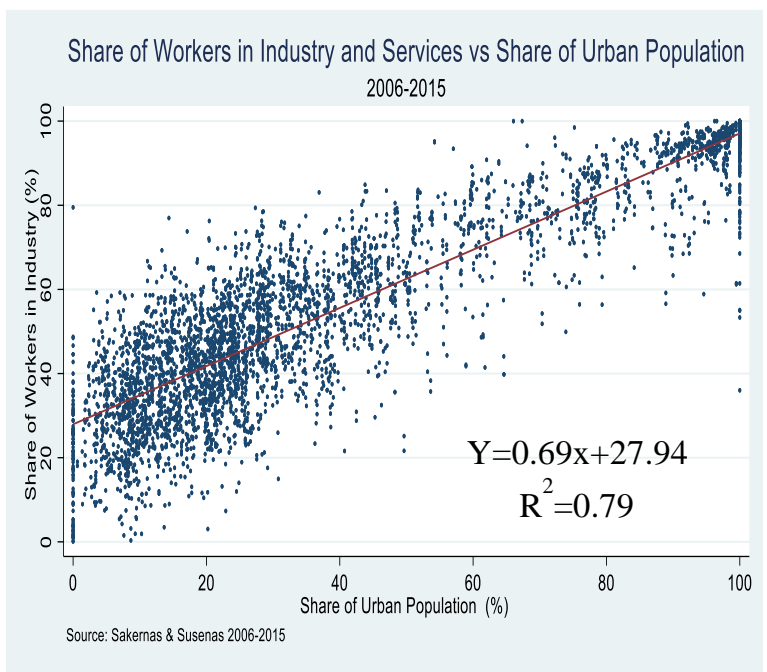

\section{Wage and Employment by Industry Group}

Table 10: Wage and Employment Structure by Industry Group

\begin{tabular}{lccc|ccc|ccc}
\hline \multirow{2}{*}{ undustry Group } & \multicolumn{2}{c|}{ Mean Hourly Real Wage (Rp.) } & \multicolumn{3}{c|}{ Gini Index } & \multicolumn{3}{c}{$\begin{array}{c}\text { Share of Employment } \\
\text { (percent) }\end{array}$} \\
\cline { 2 - 10 } & $(1)$ & $(2)$ & $(3)$ & $(1)$ & $(2)$ & $(3)$ & $(1)$ & $(2)$ & $(3)$ \\
\hline Agriculture & 5109 & 5924 & 5477 & 0.39 & 0.38 & 0.39 & 8.83 & 7.95 & 8.32 \\
Mining and & 9848 & 10811 & 10332 & 0.48 & 0.46 & 0.47 & 1.59 & 1.90 & 1.77 \\
Quarrying & 5096 & 6108 & 5571 & 0.40 & 0.42 & 0.41 & 24.49 & 23.94 & 24.17 \\
Manufacturing & 5423 & 6280 & 5841 & 0.45 & 0.46 & 0.46 & 40.00 & 41.81 & 41.05 \\
Other Business & 10879 & 12509 & 11677 & 0.39 & 0.46 & 0.42 & 25.09 & 24.41 & 24.69 \\
Activities & 7230 & 8443 & 7814 & 0.46 & 0.49 & 0.48 & 100 & 100 & 100 \\
Social Services & & & & & & & & &
\end{tabular}

Notes: Other Business Activities comprise of Electricity, Gas and Water; Construction; Trade, Hotels and Restaurants; Transportation and Communication; Real Estate; and Private Services. Time periods refer to (1) 2006-2010; (2) 2011-2015; (3) 2006-2015 


\section{BANK INDONESIA}

\section{Data Description}

\begin{tabular}{|c|c|c|c|}
\hline \multicolumn{4}{|c|}{ Databases Used } \\
\hline Name & Database & Years & Source \\
\hline Sakernas & $\begin{array}{l}\text { National Labor Force Survey of } \\
\text { Indonesia }\end{array}$ & 2006-2015 & Statistics Indonesia (BPS) \\
\hline Susenas & $\begin{array}{l}\text { National } \quad \text { Socioeconomic } \\
\text { Survey }\end{array}$ & $\begin{array}{l}2006-2015 \\
1992\end{array}$ & Statistics Indonesia (BPS) \\
\hline $\begin{array}{l}\text { INDO- } \\
\text { DAPOER }\end{array}$ & $\begin{array}{l}\text { Indonesia Database for Policy } \\
\text { and Economic Research }\end{array}$ & $2006-2015$ & $\begin{array}{l}\text { https://databank.worldbank.org/source/indonesia } \\
\text {-database-for-policy-and-economic-research\# }\end{array}$ \\
\hline $\begin{array}{l}\text { Permendagr } \\
\mathrm{i}\end{array}$ & $\begin{array}{l}\text { Minister of Home Affairs } \\
\text { Regulation No. 137/2017 on } \\
\text { Government Administrative } \\
\text { Region Coding and Data }\end{array}$ & 2017 & Ministry of Home Affairs \\
\hline
\end{tabular}

Individual-level variable descriptions

\begin{tabular}{|c|c|c|}
\hline Variable & Source & Description \\
\hline $\begin{array}{l}\text { Hourly Real } \\
\text { Wage }\end{array}$ & Sakernas 2006-2015 & $\begin{array}{l}\text { Monthly wage divided by } 4 \text { and divided by average working hours } \\
\text { per week, log transformed }\end{array}$ \\
\hline Age & Sakernas 2006-2015 & Continuous \\
\hline Gender & Sakernas 2006-2015 & Dummy with a value of 1 for female \\
\hline Education & Sakernas 2006-2015 & $\begin{array}{l}\text { Dummies based on educational attainment (no schooling, primary } \\
\text { school, junior high school, senior high school, diploma/polytechnic, } \\
\text { and bachelor-doctoral) }\end{array}$ \\
\hline $\begin{array}{l}\text { Marital } \\
\text { Status }\end{array}$ & Sakernas 2006-2015 & Dummy with a value of 1 for married \\
\hline Occupation & Sakernas 2006-2015 & $\begin{array}{l}\text { Nine dummies based on occupational classification from } \\
\text { Klasifikasi Baku Jabatan Indonesia (KBJI) } 2000\end{array}$ \\
\hline
\end{tabular}

\begin{tabular}{|c|c|c|}
\hline \multicolumn{3}{|c|}{ Region/industry-level variable descriptions } \\
\hline Variable & Source & Description \\
\hline Spatial Residual & Sakernas 2006-2015 & $\begin{array}{l}\text { Coefficients of region, industry, and year dummy interaction from } \\
\text { first stage }\end{array}$ \\
\hline Urban Density & Susenas 2006-2015 & $\begin{array}{l}\text { Computed using individual weights for the aggregation, log } \\
\text { transformed }\end{array}$ \\
\hline $\begin{array}{l}\text { Urban Density } \\
1992\end{array}$ & Susenas 1992 & Log transformed, used as an IV \\
\hline Specialization & Sakernas 2006-2015 & $\begin{array}{l}\text { Computed using individual weights for the aggregation, log } \\
\text { transformed }\end{array}$ \\
\hline Diversity & Sakernas 2006-2015 & $\begin{array}{l}\text { Computed using individual weights for the aggregation, log } \\
\text { transformed }\end{array}$ \\
\hline Competition & Sakernas 2006-2014 & $\begin{array}{l}\text { Computed using individual weights for the aggregation, log } \\
\text { transformed }\end{array}$ \\
\hline Market Access & $\begin{array}{l}\text { INDO-DAPOER } \\
2006-2015\end{array}$ & Log transformed \\
\hline
\end{tabular}




\begin{tabular}{|c|c|c|}
\hline \multicolumn{3}{|c|}{ Region/industry-level variable descriptions } \\
\hline Variable & Source & Description \\
\hline Area & Permendagri 2017 & Log transformed \\
\hline $\begin{array}{l}\text { Share of Highly } \\
\text { Educated Workers }\end{array}$ & Sakernas 2006-2015 & Proportion of workers who completed higher education per district \\
\hline $\begin{array}{l}\text { Share of Highly } \\
\text { Educated Workers } \\
1997\end{array}$ & Sakernas 1997 & Used as an IV \\
\hline Horeca/Population & Podes 2008-2014 & Number of hotels, restaurants, and cafeterias per 1000 population \\
\hline Temperature & BPS & $\begin{array}{l}\text { Absolute value of the difference between average temperature and } \\
\text { the thermal comfort standard }\end{array}$ \\
\hline Capital/Population & $\begin{array}{l}\text { INDO-DAPOER } \\
2006-2015\end{array}$ & Capital expenditure per capita, log transformed \\
\hline Industry Dummies & Sakernas 2006-2015 & 63 categories based on KBLI 2005 \\
\hline Region Dummies & Sakernas 2006-2015 & 440 districts \\
\hline
\end{tabular}

